\title{
Environmental Dose
}

Assessment Methods for

Normal Operations at DOE

\section{Nuclear Sites}

D. L. Strenge

W. E. Kennedy, Jr.

J. P. Corley

September 1982

Prepared for the U.S. Department of Energy

under Contract DE-AC06-76RLO 1830

Pacific Northwest Laboratory

Operated for the U.S. Department of Energy

by Battelle Memorial Institute 


\title{
DISCLAIMER
}

This report was prepared as an account of work sponsored by an agency of the United States Government. Neither the United States Government nor any agency thereof, nor any of their employees, makes any warranty, express or implied, or assumes any legal liability or responsibility for the accuracy, completeness, or usefulness of any information, apparatus, product, or process disclosed, or represents that its use would not infringe privately owned rights. Reference herein to any specific commercial product, process, or service by trade name, trademark, manufacturer, or otherwise, does not necessarily constitute or imply its endorsement, recommeridation, or favoring by the United States Government or any agency thereof. The views and opinions of authors expressed herein do not necessarily state or reflect those of the United States Government or any agency thereof.

\author{
PACIFIC NORTHWEST I.ABORATORY \\ operated by \\ BATTELLE \\ for the \\ UNITED STATES DEPARTMENT OF ENERGY \\ under Contract DE-AC06-76RLO 1830
}

Printed in the United States of America Available from

National Technical Information Service United States Department of Commerce 5285 Port Roval Road

Springfield, Virginia 22151

NTIS Price Codes

Microfiche A01

Printed Copy

$\begin{array}{ll}\text { Price } \\ \text { Pages } & \text { Codes }\end{array}$

001-025

026-050

051-075

076-100

$10:-125$

$126-150$

151-175

$176-200$

201-225

$226-250$ 


\section{2}

PNL-4410

UC-11

ENVIRONMENTAL DOSE ASSESSMENT METHODS

FOR NORMAL OPERATIONS AT DOE

NUCLEAR SITES

D. L. Strenge

W. E. Kennedy, Jr.

J. P. Corley

September 1982

Prepared for the

U.S. Department of Energy

under Contract DE-AC06-76RLO 1830

Pacific Northwest Laboratory

Richland, Washington 99352 
. 


\section{ACKNOWLEDGMENTS}

This work was performed for the Department of Energy, Office of Operational Safety.

The authors would like to express appreciation for manuscript editing by E. M. Toomey and word processing by R. Moreno and P. Goodenough. 
, 


\section{ABSTRACT}

Methods for assessing public exposure to radiation from normal operations at DOE facilities are reviewed in this report. The report includes a discussion of environmental doses to be calculated, a review of currently available environmental pathway models and a set of recommended models for use when environmental pathway modeling is necessary. Currently available models reviewed include those used by DOE contractors, the Environmental Protection Agency (EPA), the Nuclear Regulatory Commission (NRC), and other organizations involved in environmental assessments. General modeling areas considered for routine releases are atmospheric transport, airborne pathways, waterborne pathways, direct exposure to penetrating radiation, and internal dosimetry. The pathway models discussed in this report are applicable to long-term (annual) uniform releases to the environment: they do not apply to acute releases resulting from accidents or emergency situations. 

ACKNOWLEDGMENTS

i i i

ABSTRACT

1.0 INTRODUCTION

2.0 ENVIRONMENTAL DOSE QUANTITIES

2.1 FENCE-POST DOSE RATE

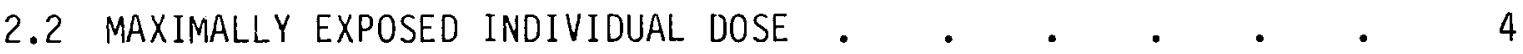

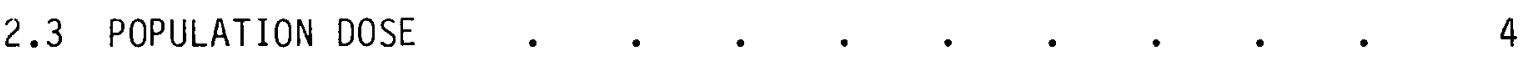

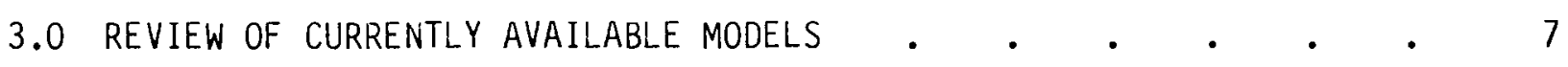

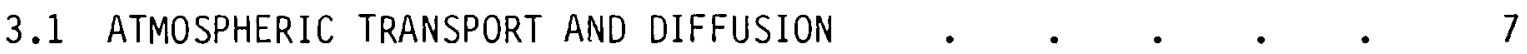

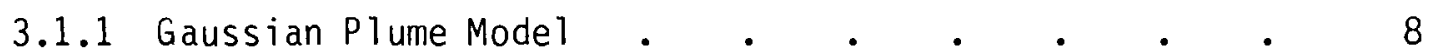

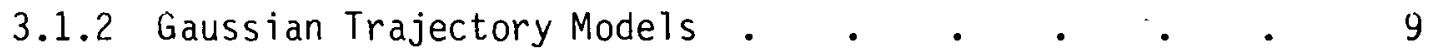

3.1.3 Finite Difference Models $\quad$ • . . . $\quad$. 10

3.1.4 Particle-in-Cell Models . . . . . . 11

3.1.5 Atmospheric Dispersion Submodels . . . . . . 11

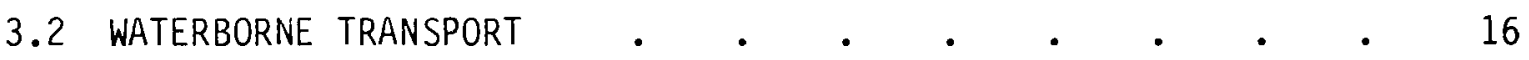

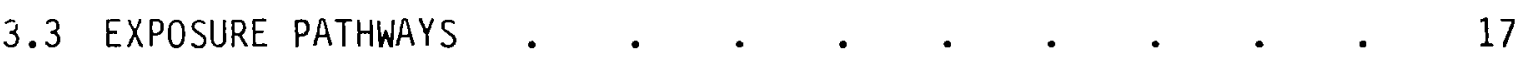

3.3.1 Exposure to Airborne Plumes . $\quad$. $\quad$. . . 17

3.3.2 Exposure from Aquatic Activities and Foods . $\quad$. 18

3.3.3 Exposure from Terrestrial Crops and

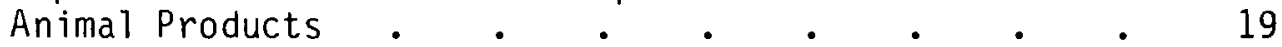

3.3.4 Direct Exposure from Contained Sources . . . 22

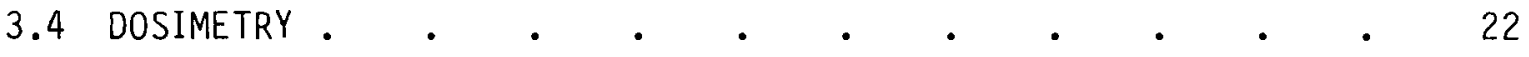

3.4.1 Use of Concentration Guides . $\quad . \quad$ • $\quad$ • $\quad$ • 23

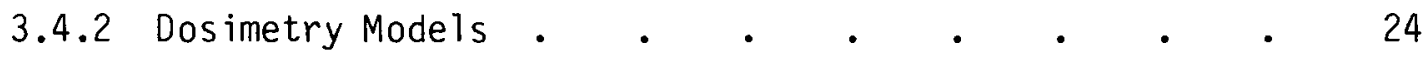

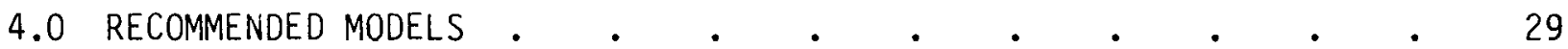


4.1 ATMOSPHERIC TRANSPORT AND DIFFUSION $\quad . \quad \ldots \quad . \quad . \quad . \quad 32$

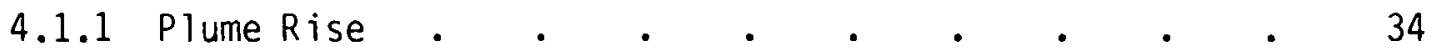

4.1.2 Building Wake Correction Model . . . . . 36

4.1.3 Terrain Elevation . . . . . . . . . . 37

4.1.4 Dry Deposition . . . . . . . . . . . . 37

4.1.5 Wet Deposition . . . . . . . . . . 38

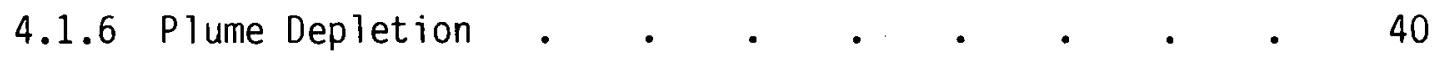

4.1.7 Mixing Depth . . . . . . . . . 43

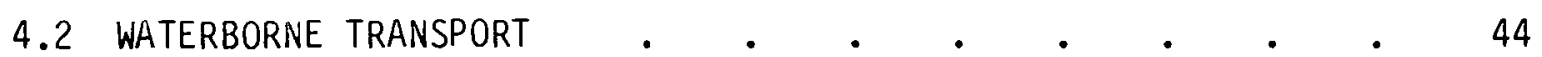

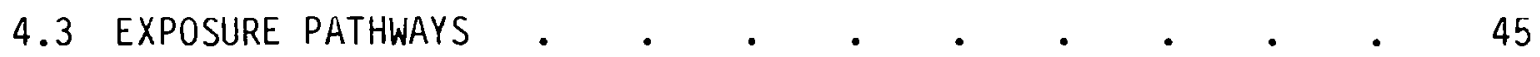

4.3.1 Exposure to Airborne Plumes . . . . . . . 45

4.3.2 Aquatic Pathways . . . . . . . . . . 50

4.3.3 Terrestrial Pathways . $\quad$. $\quad$. $\quad$. 55

4.3.4 Direct Exposure from Contained Sources _ . . . 61

4.4 DOSIMETRY .

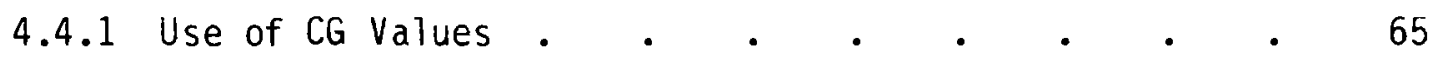

4.4.2 Dosimetry Models . . . . . . . . . . 65

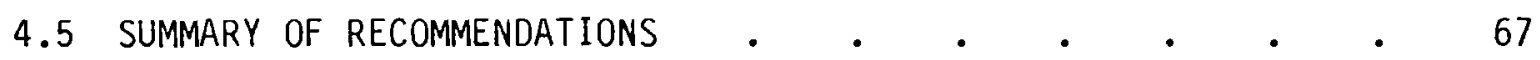

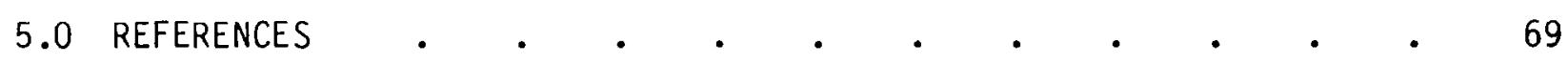




\subsection{INTRODUCTION}

This report is a review of the methods available to the Department of Energy (DOE) and its contractors to assess public exposure to radiation from normal operations at DOE facilities. Also included is a set of recommended models to be used when environmental pathway modeling is required. The critical pathway analysis procedure reported by Corley, et al. (1981) can be used to establish the need for pathway analysis at a given site.

Environmental consequence analyses usually result in estimated doses to selected receptors in the vicinity of the release site. Definitions of these dose quantities and receptor locations are provided in Section 2.

The review of models currently used for evaluating the environmental impact from chronic releases of radionuclides is given in Section 3. Models reviewed include those used by DOE contractors, the Environmental Protection Agency (EPA), the Nuclear Regulatory Commission (NRC) and other organizations involved in environmental assessments. General modeling areas considered are atmospheric transport, airborne pathways, waterborne pathways, direct exposure to penetrating radiation, and dosimetry.

Models that we recommend be used for pathway analysis are given in Section 4. Use of site-specific models is recommended when the models result in an improved representation of the real situation over our recommended models. The models were selected to meet the following criteria: the models must be applicable on a site-specific basis, site-specific parameters must be readily available or easily defined, models must be easy to implement on local computers or use readily available computer programs, and the models must provide a reasonable representation of the physical process modeled. Models for airborne transport and pathways, waterborne pathways, penetrating radiation exposure, and dosimetry are included.

The pathway models discussed in this report are applicable to normal operations involving long-term (annual) uniform releases to the environment. The models are not intended to be applicable to atmospheric releases resulting from major abnormal occurrences. However, releases of intermittent nature 
that occur throughout the year (at 1 to 2 week intervals or more of ten) may be approximated as a continuous release and the recommended models may be used. An example of such an operation would be the dissolving of spent fuel at a reprocessing plant that releases small quantities of noble gases with each batch of fuel processed. For major abnormal occurrences, general practice is to use different atmospheric dispersion models, with emphasis on use of meteorological conditions existing at the time of the occurrence.

The term "environmental pathway" is used in this report to represent a transport or accumulation process or a sequence of such processes that result in uptake of radioactivity by man. Inhalation of airborne material and consumption of contaminated milk are examples of environmental pathways.

The terms "model", "computer program" and "parameter" often cause confusion. This report uses the term "model" to represent the mathematical expression or algorithm used to describe the process being simulated. A "computer program" is a means of implementing a given model and/or sets of submodels on a computer. "Parameters" are a part of the mathematical expression of a model and the values adjusted to fit the conditions being simulated. As an example consider the overall environmental consequence analysis model for the release of radionuclides to a river. A submodel for this pathway estimates water concentration at some location downstream. Parameters used in this submodel include river flow rate and width defined for the location being studied. 


\subsection{ENVIRONMENTAL DOSE QUANTITIES}

This section describes the representative environmental dose quantities considered by DOE to provide a reasonable measure of the potential consequences resulting from routine operation of DOE facilities (DOE 1981b, Chapter III). The dose quantities are defined as a "fence-post dose rate," a "maximally exposed individual dose," and the "population dose." Details of dose calculations for each quantity (location of receptor and philosophy of calculation) are provided in the following sections.

\subsection{FENCE-POST DOSE RATE}

The fence-post dose rate is intended to provide a measure of the maximum external radiation dose from site sources in any location of uncontrolled public access. The fence-post dose rate may be determined by measurements made at selected locations about the site using environmental dosimeters recording dose rate meters or portable instruments. This dose rate represents the dose an individual would have received if he were at the given location during the entire year of operation. However, it should be emphasized that the fence-post dose rate does not represent a dose actually received by any member of the public. The dose rates determined using environmental dosimeters will necessarily include background radiation contributions such as those of cosmic origin, natural radioactive materials in the air and ground, and fallout from nuclear weapons testing. Inhalation and ingestion pathway contributions are specifically excluded from the fence-post dose rate.

For sites that have potential for release of radioactive material to surface waters, the fence-post dose rate measurement should include locations in accessible portions of the surface waters (to simulate exposure during boating or swimming) and shoreline (to simulate exposure during shoreline activities).

The location of the fence-post dose rate calculation is generally near the site boundary. However, other locations should be considered based on atmospheric dispersion calculations that may predict peak air concentrations at further downwind distances. 


\subsection{MAXIMALLY EXPOSED INDIVIDUAL DOSE}

The maximally exposed individual dose represents the maximum probable dose to any member of the public in an uncontrolled area. It is based on realistic estimates of occupancy, living and dietary habits and includes the contributions from all available exposure pathways. This dose is generally calculated using environmental models to estimate the contribution from each pathway. While each pathway contribution is credible, it is possible that no individual will actually receive the entire calculated dose nor does a specific individual need to be identified. The dose represents the 50-year commitment from one year of plant operation.

Pathways typically included in the maximally exposed individual dose calculation are external exposure from onsite penetrating radiation sources, inhalation of and submersion in airborne radioactive effluents, ingestion of food crops and animal products contaminated from dry deposition and/or irrigation, ingestion of contaminated water, ingestion of contaminated aquatic foods and external exposure to contaminated water, sediment and land. Parameter values used in the environmental pathway calculations are chosen to maximize the dose received by the individual within realistic bounds. However, average metabolic parameters are used in the dosimetry calculation for all three dose quantities discussed in this section.

For some radionuclides and exposure pathways calculation of doses to selected age groups may be warranted. An example of such a calculation is the pasture-cow-milk pathway for radioiodine which results in exposure of the thyroid gland. This calculation is generally performed using appropriate parameters for infants or young children.

\subsection{POPULATION DOSE}

The population dose represents the collective dose received by the population residing within an $80-\mathrm{km}$ radius of the site. The population dose is calculated as the sum of the product of the average individual doses and the number of persons potentially exposed. The population dose calculations are discussed in Section 4.0 (Equations 4.0-1 and 4.0-2). All potential pathways are included in the calculation as for the maximally exposed individual. Site 
specific population distribution data, atmospheric dispersion patterns and farm product production information are generally used in the population dose estimates. Parameter values used in estimating the average individual dose are chosen to represent average conditions for the region. This results in a realistic estimate of the total population dose. Environmental monitoring results may be sufficient for some pathways. As for the maximally exposed individual dose, the calculated population dose is the 50 -year dose commitment resulting from uptake received during one year of plant operation. 
. 


\subsection{REVIEW OF CURRENTLY AVAILABLE MODELS}

A variety of models are required to estimate radiation doses from the routine operation of nuclear facilities. This section reviews models currently used for environmental assessments by DOE contractors, the EPA, the NRC and other organizations involved in environmental assessments. The purpose of the review is to provide a basis for recommendation of models to be used by DOE contractors in preparation of their annual reports.

Environmental assessments of operating nuclear facilities contain estimates of radiation doses to man resulting from:

- airborne effluents

- waterborne effluents, and

- direct exposure from penetrating radiation.

Airborne and waterborne effluents involve physical transport mechanisms and are discussed individually in Sections 3.1 and 3.2, respectively. Exposure pathways to man resulting from these effluents are discussed in Section 3.3. Direct exposure from penetrating radiation involves direct radiation exposure of members of the public who reside near the site boundaries and is discussed in Section 3.3.4.

The pathway models provide radionuclide concentrations at selected exposure and uptake locations by man. Dosimetry models are then used to convert the radionuclide uptake to radiation doses. A summary of the models for radiation dose calculations is presented in Section 3.4.

A summary of models recommended for use by DOE contractors is presented in Section 4.0. The recommended models represent an acceptable methodology for the required analyses. Use of alternate models for specific applications is encouraged when a better representation of the phenomena involved is realized, e.g., site specific transport models. The need for pathway analysis at a given site can be determined using criteria reported by Corley, et al. (1981).

\subsection{ATMOSPHERIC TRANSPORT AND DIFFUSION}

Many models have been developed for estimating atmospheric transport and diffusion from point sources of airborne effluents. Several of these models 
are appropriate for calculation of air concentrations resulting from chronic airborne releases at DOE nuclear sites. The complexity of these models varies greatly from simple Gaussian dispersion models to models involving detailed numerical solutions to the mass continuity equations. A representative sample of these models is discussed briefly in the following sections and an indication is given as to their usefulness in performing chronic release atmospheric dispersion estimates. More detailed discussions of atmospheric dispersion models are provided by Rosen (1977), Turner (1979), Drake and Barrager (1979) and Hanna, Briggs and Hosker (1982). The atmospheric dispersion models discussed in the following sections are:

- Gaussian plume

- Gaussian trajectory

- finite-difference

- particle-in-cell.

\subsubsection{Gaussian Plume Model}

The most widely used model for chronic atmospheric release dispersion estimates is the Gaussian plume model. In this model the plume is assumed to travel in a straight line, at constant wind speed and at a given stability until it travels beyond the outer distance radius of interest (usually taken as $80 \mathrm{~km}$ ). These constant conditions are determined by the conditions at the time of release. The plume is assumed to spread laterally and uniformly to cover a sector in the direction the wind is blowing. Sixteen equal sectors (22-1/2 degrees) are usually used. The annual joint frequency of occurrence of wind speed, wind direction and atmospheric stability is used to weight the calculated air concentration at each receptor location to determine the average annual air concentration at each receptor location. The site-specific joint frequency of occurrence values are generally defined for the sixteen compass directions, up to seven stability classifications, and several wind speed classes (up to $25 \mathrm{mph}$ ). The data are based on observations at a single station near the release site. Submodels are often applied to the Gaussian dispersion model to account for effects of plume rise, building wake and plume depletion by dry and wet deposition. The deposition of material from the 
plume onto the ground is important to the terrestrial food pathways and for the external exposure to contaminated ground pathway. A discussion of these submodels is given in Section 3.1.5.

Examples of computer programs that use of the Gaussian plume model include XOQDOQ (Sagendorf and Goll 1977), KRONIC (Strenge and Watson 1973), CDM (Busse and Zimmerman 1973) and AIRDOS-EPA (Moore et al. 1979).

The advantages of the Gaussian plume model are the simplicity of use and the short computational times. The major input data requirement is annual averaged joint frequency data for a single station near the site. Simple decay schemes are also handled quite easily. The major disadvantage to use of the Gaussian plume model is the poor representation of actual dispersion patterns beyond a few kilometers. This model is only good for relatively flat terrain away from coastlines and large water bodies and it does not address changes in plume direction during downwind transport. Periods of calm winds are also difficult to handle and are usually distributed into the lower windspeed categories.

\subsubsection{Gaussian Trajectory models}

Gaussian trajectory models are an extension of the Gaussian plume model designed to allow for time variation of meteorological conditions. These models predict the path and spread of a continuous release as windspeed, direction and atmospheric stability change with time. Data required by Gaussian trajectory models consists of hourly sequential observations of wind speed, wind direction, and stability from one or more locations in the region of the release site. The observation data set defines the wind field in the vicinity of the release site. Annual average air concentrations at each location of interest are determined from a probability distribution of concentrations based on trajectory statistics.

An example of application of a Gaussian trajectory model is the family of MESODIF computer programs (Start and Wendel 1974; Powell et al. 1977).

Advantages to Gaussian trajectory models include consideration of the time variability of atmospheric conditions with respect to plume trajectory and a better representation of low wind conditions. The effects of wind reversal 
and multiple passes are represented in the trajectory analysis. Also some trajectory models consider time variation of atmospheric stability.

The main disadvantage is that the Gaussian trajectory models are limited to generally flat terrain although use of data from many observation stations may implicitly include effects of terrain on wind patterns. The computer time required to perform a trajectory analysis in calculating annual average concentrations is considerably longer than for the simpler Gaussian plume models. Also the input data requirements are generally greater for Gaussian trajectory models because extensive wind data is needed to give significantly improved results over Gaussian plume models.

\subsubsection{Finite Difference Models}

Finite difference (or grid) models involve numerical solution to the transport and diffusion equations by finite difference approximations. The region to be modeled is divided into a network of constant volume cells. The net flux of pollutant across each cell boundary is then calculated considering turbulent diffusion, advection, and sources and sinks (such as chemical reactions). These models are useful for short-term analysis of reactive pollutants over urban and regional areas. The results give concentration at grid points over the area of interest. Input to the finite difference models is in the form of windfields which must include effects of complex terrains such as channeling in valleys and plume impingement on ridges. Some models allow for direct input of terrain elevations.

Examples of computer programs using the finite difference technique are LIRAC (MacCraken et al. 1975) and a program developed at Systems Application, Inc. (Reynolds et al. 1973).

While these finite difference computer programs are probably best able to account for complex effects of terrain and chemical reactions, they require signficant computer time and storage. Extension of the short-term analysis to provide annual average concentrations would require prohibitive amounts of effort in wind field preparation and computer analysis time. 


\subsubsection{Particle-in-Cell Models}

The particle-in-cell (PIC) models follow the transport of specific pollutant particles within a fixed grid system. The concentration at any given time is found by counting the particles within each grid cell. Input requirements for PIC models includes a definition of the velocity field (including turbulence corrections) for the region of interest. Like the finite difference models, the PIC models are designed for short-term analysis and use for calculating annual average concentrations is difficult.

An example of a computer program that implements the PIC model is the ADPIC computer program (Lange 1973) developed at Lawrence Livermore Laboratory.

The major difficulty in the use of PIC models is the need to track a large number of particles to obtain reasonable accuracy. This results in use of large amounts of computer time and storage. The main advantage to PIC models is that they reduce the problem of numerical diffusion and simulate advection more accurately than do other models. This results in a better representation of transport processes for non-reactive pollutants.

\subsubsection{Atmospheric Dispersion Submodels}

The basic atmospheric dispersion calculations are of ten modified to account for small-scale phenomena that may have an effect on downwind radionuclide concentrations. This section contains reviews of models currently used for the following atmospheric dispersion submodels:

- plume rise

- building wake

- terrain variation

- dry deposition

- wet deposition

- mixing depth.

The plume rise models estimate the added elevation achieved by the plume and results in lower air concentrations at near release locations with less of an effect at longer distances. The increased dispersion at the source due to building wake effects also causes lower air concentrations near the release location with little effect at longer distances. The effect of terrain 
variations on calculated air concentrations can be large and is difficult to estimate. The removal of material from the plume due to wet and dry deposition processes can have a significant effect at long distances from the release point. The effect of the atmospheric mixing depth is to increase air concentrations somewhat at long distances. Each of these submodels are discussed in detail below.

Plume Rise - When releases from elevated points (i.e., stacks) contain excess heat or are released with significant vertical velocity the resulting plume may rise to a level above the actual release point. Plumes with excess heat rise due to the added buoyancy of the hot air while plumes with significant velocity rise due to the momentum of the exiting material. The appropriate model to use depends on the characteristics of the effluent plume. Models are available for both momentum and buoyancy dominated releases. Routine release effluent streams are usually near ambient conditions (little excess heat) and may be described by momentum plume rise models.

The models of Briggs $(1969,1975)$ are generally used to estimate the increment to the effective plume height caused by plume rise (momentum or buoyancy dominated). The equations suggested by Briggs consider the effects on plume rise of atmospheric stability, windspeed, travel distance, effluent heat content and effluent velocity.

Plume rise models are designed for application to dispersion from tall stacks where the effluent is free from wakes of adjacent buildings. Sagendorf and Goll (1977) suggest use of a mixed release mode for vent (lower level) releases where the release is divided into elevated and ground components. This mixed model representation was developed for routine release situations.

Building Wake Correction - Material released from building vents, short stacks or at ground level may be subject to enhanced dispersion due to the turbulent wake caused by air flow around the building. Building wake corrections are generally considered for ground level releases only. The general method for estimating the effect of the building wake is to consider the release to be a volume source. The size of this volume source is related 
to the size of the building. For Gaussian dispersion models, the volume source is represented by increasing the numerical values of the plume dispersion coefficients. Versions of this method are described by Slade (1968), USNRC (1977) and Sagendorf (1974). All of these versions are roughly equivalent.

Terrain Variation - The ground-level air concentration is dependent on the effective height of the plume centerline for most dispersion models. For areas where the terrain is essentially flat, the centerline is at a constant elevation (after plume rise). Terrain variation models attempt to estimate the effect of terrain elevation changes on the effective plume height. Three models are presented in Regulatory Guide 1.111 (USNRC 1977b):

- horizontal plume model

- terrain conformal model

- a combination of the above.

For the horizontal plume model a terrain elevation value is subtracted from the effective stack height. The value to subtract is taken as the maximum terrain height between the release point and the exposure point. The terrain height for purposes of this correction is the height above the stack base and must be greater than or equal to zero.

In the terrain conformal model it is assumed that the plume follows the contour of the terrain and hence the plume centerline is always a constant height above the ground.

As an alternative method, Regulatory Guide 1.111 suggests the use of Egan's (1975) method for unstable and neutral conditions and Burt's (1977) method for stable conditions. Egan's method assumes an intermediate trajectory halfway between the terrain conformal and horizontal plume models. Burt's method assumes the plume to be horizontal until the terrain rises to within 10 meters of the plume centerline. Then the plume is assumed to be terrain conformal at a distance of 10 meters above the terrain.

In recent work performed for the EPA Bass, Strimaitis, and Egan (1981) have described a potential flow model to estimate the effects of simple terrain features on Gaussian plume dispersion. Their model considers neutral and 
slightly stable conditions (based on both theoretical and experimental studies). The model could be of use when simple shaped hills are present. However, for typical rough terrain involving multiple irregularly shaped hills the model would not apply without further work.

For sites with complex terrain the enhanced dispersion caused by terrain variation can be approximated by shifting the Pasquill-Gifford stability classification one classification towards unstable conditions (Bass, Strimaitis and Egan 1981).

A more significant effect of local terrain variations on dispersions is the potential for directional flow variations, i.e., valley conditions or sites dominated by drainage winds. Such effects must be analyzed on a site-specific basis. Use of complex atmospheric dispersion models may be warranted for such cases.

Dry Deposition - Dry deposition includes removal of particulates and gases from plumes by the processes of settling, absorption on plants, and impaction. Dry deposition models generally assume that radioiodines and particulates behave similarly with no removal of noble gases.

The removal of a material from the plume by dry deposition processes can be described by source depletion models and surface depletion models. Source depletion models allow for uniform removal of activity from the cloud at progressive downwind distances. Surface depletion models consider nonuniform vertical concentration profiles resulting from activity removal at the airground interface. Horst $(1979 a, 1979 b)$ developed a model for correction of the Gaussian plume model for the surface depletion of nonsettling particles. This model reduces the source strength in the Gaussian model as a function of downwind distance to account for both the loss of airborne material and for the change in vertical profiles. Horst's model is actually a hybrid surface depletion/source depletion model.

An example of a source depletion model is given in Regulatory Guide 1.111 which presents curves defining plume depletion and ground deposition for routine release situations. These curves define correction factors to be applied to plume concentrations at ground level to determine the depleted plume 
concentration. Additional curves are presented to estimate ground deposition. All of these functional relationships are presented as a function of release height, atmospheric stability, and downwind distance. The figures are based on measurements of deposition velocity reported by Pelletier and Zimbrick (1970) and on a diffusion model as presented by Markee (1967).

The general method for estimating the ground concentration is by use of an effective deposition velocity. The effective deposition velocity is generally assumed to be constant for a given radionuclide and includes effects of settling, diffusion and impaction.

Wet Deposition - The many physical processes involved in wet deposition make this an area difficult to predict and model accurately. Regulatory Guide 1.111 suggests that wet deposition is not generally of significance for routine release situations because of the relatively small time the precipitation is likely to occur. If analysis shows that precipitation may be significant for a particular site, it is suggested that washout rates and plume concentration be calculated according to methods given by Engleman (1968). Engleman suggests using an exponential expression for the air concentration during periods of precipitation. The IAEA (1980) has suggested a form of the Engleman equation to estimate the ground deposition rate. Their expression requires assumptions be made on the spatial distribution of rain showers with time.

Mixing Depth - The vertical expansion of the plume may be limited by the mixing depth which is atmospheric stability dependent. Values of the mean mixing depth throughout the U.S. are presented by Holzworth (1972). Values are given for mornings and afternoons by season and for the annual average. Turner (1969) has suggested a scheme to account for effects of the mixing height on plume expansion that limits the increase of the Gaussion plume vertical standard deviation parameter. When the vertical dispersion parameter is very near the mixing depth the plume is assumed to be uniformly distributed in the mixing layer. This results in a slight discontinuity at the distance where the mixing depth is reached. Another approach (Sagendorf and Goll 1977) is to limit the value of the vertical standard deviation of plume concentration 
parameter to a maximum value. Busse and Zimmerman (1973) have suggested that values used for the mixing depth (from Holzworth 1972) be related to atmospheric stability.

\subsection{WATERBORNE TRANSPORT}

Release of radionuclides to surface water or ground water may result in radiation exposures to individuals and the population near the release site. Water transport models are needed to estimate radionuclide concentrations at selected locations in the environment. For routine releases the exposure pathway models (see Section 3.3) are based on steady-state concentrations. The general method for determining steady-state concentrations is to use dilution factors that give the average radionuclide concentration $\left(\mathrm{Ci} / \mathrm{m}^{3}\right.$ or $\left.\mathrm{Ci} / \mathrm{l}\right)$ at each location of interest normalized to a release of one curie per year. These dilution factors may be modified to include effects of radiological decay in transit for specific radionuclides.

The Liquid Pathway Generic Study of the U.S. Nuclear Regulatory Commission (USNRC 1978), Regulatory Guide 1.113 (USNRC 1977a) and Strenge et al. (1978) provide a review of surface water models available for waterborne dispersion under acute and routine release situations for dispersion in rivers, estuaries, large lakes and along open coasts. The models discussed range from simplified models having analytical solutions to complex models requiring numerical solution. Extensions of these models for continuous releases is suggested through the use of convolution integrals. A steady-state model is also presented to described transport through a river system with a series of reservoirs with effects of sediment layers considered. A recent report of the Commission of the European Communities (1979) has suggested a semi-imperical model for river transport with effects of sediment transport also considered. Details of these models are not discussed here. The selection of a particular model must include consideration of the specific conditions under which it will be applied. Because the application is so very site specific (except possibly for direct release to a large smooth flowing river), the determination of waterborne dilution factors must be made on a case-by-case basis using available site specific data. 
Groundwater transport is particularly difficult to estimate. Exposures from the contamination of ground water are best estimated from monitoring data giving activity levels at usage locations (i.e., wells used for drinking or irrigation). Therefore, groundwater transport models were not considered in the present review.

\subsection{EXPOSURE PATHWAYS}

The estimation of annual environmental dose from routine radionuclide releases must include consideration of all potential pathways by which radioactivity and radiation may reach man. While it is likely that only a few pathways will have a significant contribution to dose at a given site, all pathways should be considered carefully before any are dismissed as un important.

This section reviews the exposure pathways that are described in the literature. The discussion considers pathways of four types:

- exposure to the airborne plume

- exposure via aquatic foods and activities

- exposure from terrestrial crops and animal products

- direct exposure from contained sources

Each of these exposure types is specifically related to airborne effluents, waterborne effluents or direct radiation except for the terrestrial pathway which may have contributions from airborne releases (deposited onto farmland) and/or waterborne releases (deposited via irrigation).

\subsubsection{Exposure to Airborne Plumes}

Radioactive material released to the atmosphere may cause radiation exposure during plume passage. The exposure may be from external radiation as individuals are submersed in the plume or from material taken into the body via inhalation. Methods for calculation of doses from these pathways generally use dose conversion factors to relate annual average air concentrations to dose. Examples of such dose conversion factors may be found in Regulatory Guide 1.109 (USNRC 1977c) and Hoenes and Soldat (1977). 
External exposure is usually calculated for the uniform exposure of the whole body at a tissue depth of approximately $5 \mathrm{~cm}$. At this depth the contribution from beta radiation is not significant except for a few radionuclides that have a large bremsstrahlung production. The gamma exposure is generally calculated for routine releases by the semi-infinite plume model. In this model the individual is assumed to be submersed in a plume of uniform concentration throughout and bounded by the ground plane. The dose rate is then calculated as one-half the radiation energy emission rate per unit volume. The semi-infinite model is applicable to large plumes. This condition is met for most routine release situations at distances beyond $1 \mathrm{~km}$. The alternative method for calculating external penetrating radiation dose is to consider the finite size of the plume and integrate the dose contribution over the plume volume. This method is known as the finite plume model and is generally used for small plumes or elevated plumes near the release point.

Inhalation doses are calculated from the air concentration at the location of interest. The uptake is based on the assumed breathing rate. The uptake is then converted to dose using unit uptake dose converstion factors generated from internal dosimetry models discussed in a later section.

\subsubsection{Exposure from Aquatic Activities and Foods}

The exposure pathways in this category are directly related to water concentrations and include ingestion of water and aquatic foods plus external exposure from proximity to water (boating and swimming) and contaminated shore1ine. Ingestion of farm products contaminated by irrigation water is considered under terrestrial pathways.

Radionuclide contaminated water may be consumed by persons via municipal water supplies, wells, or direct withdrawal from a body of fresh water. In general, the dose to a person is dependent on the concentration of the nuclide in the water and the quantity of water ingested. For routine releases the uptake is calculated from the average water concentration at the point of consumption. Water treatment plant purification factors are of ten applied when appropriate. Some data is available on water plant removal factors for a few sites (Denham and Soldat 1975; Corey and Boni 1975) and could be extended to other sites that use similar water treatment processes. 
The concentration in aquatic foods is generally calculated assuming the aquatic organism of interest to be in equilibrium with the surrounding water ( $N$ apier et al. 1980; USNRC 1977c). Under equilibrium conditions the organism concentration is related to water concentration by a bioaccumulation or concentration factor. Bioaccumulation factors currently in use by the NRC are specified in Regulatory Guide 1.109 and were taken principally from Freke (1967) and Thompson et al. (1972). Site specific modifications to these bioaccumulation factors may be warranted in special cases (Napier 1981).

Persons exposed to contaminated waters (usually in recreational pursuits such as swimming, boating or skiing) may receive a direct radiation dose from contaminated waters. The general method for estimating this radiation dose is to assume a constant water concentration and an average usage time (hours per year) for each recreational activity. For a given duration of exposure, persons swimming (total immersion) receive a higher dose by a factor of 2 than those boating or water sking (partial immersion or surface activities) because of the assumed spherical and hemispherical geometry, respectively.

Radionuclides deposited on the shores of rivers, lakes, or oceans may accumulate over a period of time leading to external irradiation of persons standing on contaminated surfaces. The amount of the nuclides built up on the shorelines depends on the concentration in the water, the depth of deposit, and the period of buildup. The dose to persons depends on the time period spent on the contaminated surfaces.

The concentration in shoreline sediments is generally estimated from an empirical equation derived by Soldat et al. (1974) from measurements on water and sediment concentrations on the Columbia River. The calculation uses external dose conversion factors for an infinite plane source at a distance of one meter. These factors are then modified by a "shore width factor" to account for the finite dimensions of most shores.

\subsubsection{Exposure from Terrestrial Crops and Animal Products}

Contamination of lands by either deposition from air or irrigation water can result in exposure to man by four routes: 
1. external exposure to contaminated ground

2. inhalation of resuspended material

3. ingestion of contaminated crops

4. ingestion of contaminated animal products

Persons in the vicinity of the contaminated ground are subject to radiation exposure from gamma radiation. The degree to which the contamination is retained on soil with time affects the resulting external exposure. The model of Regulatory Guide 1.109 (USNRC 1977c) uses no reduction due to weathering. Another factor reducing external dose is the shielding afforded by structures. Burson and Profio (1975) have summarized shielding factors for several activities and for various structures. The effective shielding factor for any population depends on average occupancy times for buildings and activities in the vicinity of the contamination. Regulatory Guide 1.109 suggests a structural shielding factor of 0.7 for exposure of individuals and 0.5 for exposure of populations. A ground roughness factor of 0.5 is also included in the dose factors for standing on contaminated ground as given in Table E-6 of Regulatory Guide 1.109 .

In calculation of the inhalation dose from resuspension, some fraction of the ground contamination is assumed to become airborne and be inhaled by persons in the immediate vicinity. An evaluation of plutonium resuspension by Anspaugh (1975) has suggested an initial value of $10^{-4} \mathrm{~m}^{-1}$ for the resuspension factor decreasing to a value of $10^{-9}$ after 17 years. The resuspension factor relates ground concentration to air concentration. This model does not consider dependence of resuspension rate on soil roughness or vegetative cover. Such factors could have a significant effect on resuspension. However, characterization of these factors is not presently at a state where model modification is warranted. The dose from this pathway is usually small compared to the inhalation dose from the initial plume and is generally not considered in environmental dose analyses.

The airborne release pathway can result in contamination of farm products including vegetables, fruit and animal products. Vegetation can be contaminated by both direct deposition and by root uptake from contaminated soil. Animal products including meat and milk (and milk products) are contaminated 
through animal ingestion of contaminated pasture, grains and hay. All of these pathways are considered in the routine release models of Regulatory Guide 1.109 (USNRC 1977c).

The potential dose for the crop pathway can be estimated by considering sequentially the factors influencing uptake and transport to man. The important factors to be considered are:

- Fraction of initial deposition retained on plants

- Resuspension onto foliar parts of plants

- Translocation of direct deposition from surfaces to edible parts of plants

- Removal of initial deposition from vegetation by weathering

- Plant/soil concentration factor

- Change in availability from soil to roots with time

- Delay time between harvest and consumption

- Consumption by man.

The radionuclide concentrations in food crops contaminated via irrigation depend upon the same list of factors given above plus:

- Concentration in irrigation water and buildup in soil

- Fraction of deposition retained on plants

- Irrigation rate, timing and type (e.g., flooding or sprinkling).

Concentrations in animal products are dependent on the quantity of animal food consumed and the concentrations in the feed crops; the latter are controlled by the factors listed above for food crops. Additional factors include:

- Intake by animal of contaminated food (consumption rates)

- Intake by animal of contaminated water (consumption rates)

- Transfer of radionuclides to various animal products

- Delay time between slaughter or collection and consumption (as in the case of milk and eggs). 
Generic values for most of these factors are given in Regulatory Guide 1.109, which should be used only when site-specific values are unavailable or questionable.

\subsubsection{Direct Exposure from Contained Sources}

Facilities with large sources which generate penetrating radiation can potentially cause radiation exposure to members of the public if the boundary of the restricted access area is sufficiently close. An example of such a facility is the gamma forest ${ }^{137} \mathrm{Cs}$ source (now decommissioned) at Brookhaven National Laboratory. The exposure from such sources can be estimated by extrapolation of dose rate measurements taken outside the facility. In the absence of such measurements theoretical formulas for radiation transport can be used to estimate exposures. Effects of beam attenuation and energy buildup must be accounted for.

The radiation exposure received in the vicinity of high-energy particle accelerators is due mainly to neutrons ( $R$ indi and Thomas 1973). The variation of dose as a function of distance can be estimated using the inverse square relationship with an attenuation factor of the form exp $(-d / \lambda)$ where $d$ is the distance from the target and $\lambda$ is the effective attenuation length of highenergy neutrons. A slightly modified form contains the same attenuation term but assumes the distance dependence to be inversly proportional to the first power of distance (Lindebaum 1961).

\subsection{DOSIMETRY}

Two methods are in general use for estimating radiation dose from environmental concentrations:

- comparison with concentration guide values for air or water

- use of dosimetry models for external and internal exposure

The first method uses Concentration Guides (CG) currently provided in DOE order 5480.1A (DOE 1981a) which were taken from ICRP Publication 2 (ICRP 1959) with minor corrections. The second method calculates doses based on metabolic models for man to describe deposition and retention in organs of interest. The Concentration Guide values were determined using such dosimetric models, therefore a relationship exists between the two methods. 
The purpose of the dosimetry calculations is to determine the dose received by a given receptor group. This estimate is then compared to radiation standards (as described below). Care must be taken to ensure that the calculated doses correspond in uptake period and dose commitment period to the radiation standards they are to be compared with. The DOE radiation standards are intended to represent the 50-year commitment resulting from one year of uptake received during the year of operation. The concentration guide values are also equivalent to a 50-year commitment from one year of uptake.

\subsubsection{Use of Concentration Guides}

ICRP Publication 2 (1959) presents maximum permissible concentrations (MPC) in air and water for many radionucides. The MPC values are based on maximum allowable doses to workers for long-term occupational exposure. The dose limits are for the dose received during the fiftieth year of a continuous uptake resulting from air (inhalation and external) and water (ingestion) exposure. This dose value is numerically equivalent to the 50-year dose commitment from a one-year exposure. In DOE Order 5480.1A Chapter XI, radiation protection standards are defined for individuals in controlled and uncontrolled areas. The corresponding air and water concentration guides are also presented. For annual environmental reports for the DOE sites, the standards of interest are those for uncontrolled areas. These standards are given in Table 3.4-1, below (taken from DOE 1981a) and represent the dose received from one year of plant operation. While not expressly stated in the standard, the dose guides should be assumed to represent the 50-year dose commitment from uptake received in the year of plant operation. This is necessary for the dose guides to be compatible with the concentration guides.

The CG values for air and water are based on these dose limits. For a given radionuclide the dose to each organ of interest is calculated. By comparison to the dose limits the critical organ is determined. The $C G$ values are then based on exposure to the critical organ. 
TABLE 3.4-1. Radiation Standards for Uncontrolled Areas Annual Dose Equivalent or Dose Commitment, rem

$\frac{\begin{array}{l}\text { Type of } \\ \text { Exposure }\end{array}}{\text { Whole Body, Gonads or Bone Marrow }}$

Other Organs
Individuals at

Points of Maximum Probable Exposure

0.5
Average Individual in a Suitable Population Sample

0.17

\subsubsection{Dosimetry Models}

Dosimetry models are used to describe the metabolism of inhaled and ingested radionuclides in determining the dose delivered to various organs. External dosimetry models are used to describe the distribution of energy deposition within the body. In order to determine internal dose it is necessary for the models to describe deposition, translocation, organ uptake and el imination of radioactivity within the body. Dosimetry models are presented in several publications of the International Commission on Radiological Protection (ICRP 1959; Morrow 1966; ICRP 1972 and ICRP 1979). In ICRP Publication 2 (1959) basic data and models are presented for inhalation and ingestion of radionuclides. This publication forms the basis of the concentration guides for air and water presented in DOE Order 5480.1 Chapter IX (1981a).

The model presented to describe the dosimetry of the gastrointestinal tract considers four distinct compartments: stomach, smal1 intestine, upper large intestine and lower large intestine. The ingested material enters through the stomach and travels sequentially through each compartment. Absorption of material into the blood is only considered to occur in the small intestine.

The model presented in ICRP Publication 2 and used for the dose conversion factors found in Regulatory Guide 1.109 assumes that material entering the stomach resides there for one hour and then moves in a batch to the small intestine. Flow through the small intestine and large intestine is assumed to be continuous and linear. The critical tissue in the intestine is considered 
to be the wall. The dose is therefore calculated as one-half the dose to the mass of the contents. For alpha radiation a factor of 0.01 is also applied to the effective energy to account for the ineffectiveness of alpha particles in reaching the sensitive cells of the stomach and intestine walls.

A modification to this gastrointestinal tract model is presented in ICRP Publication 30 (ICRP 1979) with parameters from ICRP Publication 23 (1975). In this model each of the four compartments are characterized by exponential emptying in sequence. The average dose to the entire length of the wall of each compartment is calculated from the activity using factors of Snyder et al. (1974) based on Monte Carlo type calculations. This model is mathematically quite different from the model of ICRP Publication 2. The ICRP Publication 2 model assumes a batch flow through the stomach and linear (plug) flow through the remaining three compartments. In addition, the latter model calculates the dose only at the entrance to each of the intestine compartments, since these are normally the most highly exposed portions of the wall.

The lung model of ICRP Publication 2 provides a general model for intake of radionuclides into the body. The distribution of inhaled particulate material within the body is described for two classes of compounds: readily soluble compounds and insoluble compounds. For both classes of compounds it is assumed that $25 \%$ of the inhaled material is quickly exhaled, $50 \%$ is deposited in upper respiratory passages (and subsequently swallowed) and the remaining $25 \%$ is deposited in the lungs. For insoluble compounds half of the amount deposited in the lungs is assumed to be swallowed in the first 24 hours and half is assumed to remain in the lungs with a 120-day half-life (except for plutonium and thorium which have 1-year and 4-year half-lives, respectively). The total amount of insoluble material swallowed (i.e., that reaches the GI tract) is then $62.5 \%$. Material classed as "insoluble" is not absorbed from the small intestine and only the GI tract receives a radiation dose. For readily soluble compounds $50 \%$ reaches the GI tract. The $25 \%$ initially deposited in the lung is assumed to be taken up immediately into the body (via the blood). 
In 1966 the ICRP Task Group on Lung Dynamics published (Morrow 1966) a model for the respiratory system to describe deposition and translocation of particulates following inhalation. This model has been revised slightly and published in ICRP Publication 19 (ICRP 1972) with application to actinide inhalation.

The mathematical model for calculating the dose to an organ of interest via inhalation using the ICRP Task Group Lung Model (TGLM) is considerably more complex than that utilized by the lung model initially recommended by the ICRP. In the TGLM, the respiratory tract is divided into three regions, the nasopharyngeal (NP), the tracheobronchial (TB), and the pulmonary ( $P$ ). Deposition is assumed to vary with the aerodynamic properties of the aerosol and is described by the three parameters $D_{3}, D_{4}$ and $D_{5}$. These parameters represent the fraction of the inhaled material initially deposited in the NP, TB and $P$ regions, respectively. Each of the three regions of deposition are further subdivided into two or more subcompartments, each representing the fraction of material initially in a compartment that is subject to a certain clearance process. Material is cleared from the subcompartments to the blood, lymphatic system or GI tract. A portion of the material entering the lymphatic system and the GI tract may also reach the blood. Transport of the radionuclides from the respiratory tract, lymphatic system, and GI tract to other organs and tissues where significant accumulations of the inhaled radionuclide occur, is assumed to take place via the blood. This translocation from the respiratory tract and lymphatic system to the blood has been described in considerable detail (Morrow 1966). A constant fraction of any "soluble" material clearing from the respiratory tract through the GI tract is assumed to be taken up by the blood while passing through the small intestine.

The ingestion and inhalation models describe uptake and translocation of material to other organs. Elimination from the organs is described by a single exponential expression for each organ in ICRP Publication 2. The organ models of ICRP Publication 30 (ICRP 1979) suggests use of multiple exponential retention functions (up to five). In the ICRP Publication 2 organ dosimetry model the radionuclide is assumed to be located in the center of a spherical organ of proper effective radius. All particle radiations emitted are absorbed 
within the organ; all photon radiations are partially absorbed depending upon the organ radius and photon energy. The potential contribution to organ dose from photon radiation originating outside of that organ is ignored.

The model presented in ICRP Publication 30 includes the contribution to a "target" organ from photons originating from atoms of the radionuclide decaying in other "source" organs. These contributions had previously been calculated by a Monte Carlo method using a mathematical phantom containing more realistically shaped organs (Synder et al. 1974).

Inhalation and ingestion dose factors are generally of the same order of magnitude for the two methodologies. Disagreement is due mainly to the differences in metabolic models used, including organ uptake and retention parameters. Most other factors affecting internal dose computations are treated similarly by the two methodologies.

Exposure to radiation external to the body is considered for submersion in the contaminated plume, from exposure to contaminated ground (or shoreline) and from exposure to contaminated water (boating and swimming). Radiations of principal concern to these pathways are beta and gamma radiation. Both beta and gamma radiation are considered when calculating exposure of the skin. However, for whole body dose only gamma radiation and bremmstrahlung are considered because of the relatively short range of beta particles in tissue. Sk in dose is calculated at a tissue depth of $7 \mathrm{mg} / \mathrm{cm}^{2}(0.007 \mathrm{~cm})$ which corresponds to the depth of the basal layer cells of the epidermus (U.S. Department of Commerce 1954). The whole body dose is normally calculated for a tissue depth of $5 \mathrm{~cm}$. This dose is then assumed to apply to all internal organs of the body as suggested by NCRP (1975). Another method for estimating internal organ dose from external radiation relies on dose conversion factors calculated by Poston and Snyder (1974) for a phantom. These dose conversion factors are calculated for each organ of interest as a function of the photon energy emitted in the semi-infinite cloud. Dose conversion factors calculated by these methods agree quite well.

The external exposure during boating and swimming is calculated for submersion in an infinite medium (half infinite for boating). Considerations of tissue depths are the same as described above for air submersion. 
, 


\subsection{RECOMMENDED MODELS}

The models recommended for analysis of routine releases from DOE sites are described in this section. These models have been selected with the following criteria in mind.

- The models should be applicable on a site-specific basis (using site-specific parameters).

- Site-specific parameters for the models should be readily available or easily defined.

- The models should be easy to implement on local computers or use readily available computer programs.

- The models should provide a reasonable representation of the physical process being modeled.

The models presented in this section are considered to represent the minimum effort required to perform a thorough environmental analysis for routine releases. The models presented are not intended to preclude use of other models. In fact, some DOE sites have developed special models to describe particular local features or conditions. Use of such site-specific models is recommended provided the models do result in an improved representation of the real situation over the models presented in this section.

Use of the environmental pathway models presented in this section must be coordinated with available environmental monitoring results. Measured radionuclide concentrations in air, water or food, and penetrating radiation measurements (such as from environmental dosimeters) are the prefered bas is for estimating dose received by members of the public. Environmental pathway models are to be used when measurements are not available for a particular pathway or when the concentrations are below the minimum detectable limits. The minimum detectable concentration varies considerably among radionuclides. Also the amount of each radionuclide in the environment can vary by orders of magnitude depending on operations conducted at the site. Therefore the dose contribution from a given pathway may be estimated sufficiently from measurements for some radionuclides while a pathway analysis will be required for others. 
The pathway models are also useful in establishing environmental monitoring programs as discussed by Corley, et al. (1981). In doing so, all potential exposure routes to the public must be examined. Consideration must be given to specific radionuclide behavior in each pathway to ensure that the most useful environmental data will be obtained. Examples of such considerations include the following: radioiodine and radiostrontium contribute through the air-forage-cow-milk pathway; noble gas exposure is primarily from external radiation; deposition of noble gases is negligable; game birds or animals consuming radioactivity onsite may travel offsite where they can be shot by sportsmen presenting an ingestion pathway. Other special situations could also be mentioned. Models presented in this section can be applied to all of these situations to estimate the dose received by the potentially exposed members of the public. As mentioned previously, the starting point in the dose calculation depends on the availability of environmental monitoring data for the pathway under consideration.

Detailed mathematical descriptions of each recommended model and submodel are presented below. The models are described in the same order as the model Review Sections 3.1 to 3.4 .

Reference is made frequently in the following sections to decay correction in transit. Detailed equations for radionuclide decay are not provided in this report. The reader is referred to standard radiation physics textbooks for a mathematical description of radiological decay.

The estimation of the population dose within $80 \mathrm{~km}$ requires a spatial definition of several parameters about the site. The models recommended for atmospheric pathways are defined for a conventional radial grid system as shown in Figure 4.0-1. The annual average air concentration and the population distribution are defined at each spatial interval within this grid.

The exposure pathway and dosimetry models allow estimation of doses received by individuals in the vicinity of the facility under study. The individual doses are usually calculated for a specific spatial interval (as defined in Figure 4.0-1). All individuals within a given spatial interval are assumed to receive the same dose for each pathway of significance. The population dose 


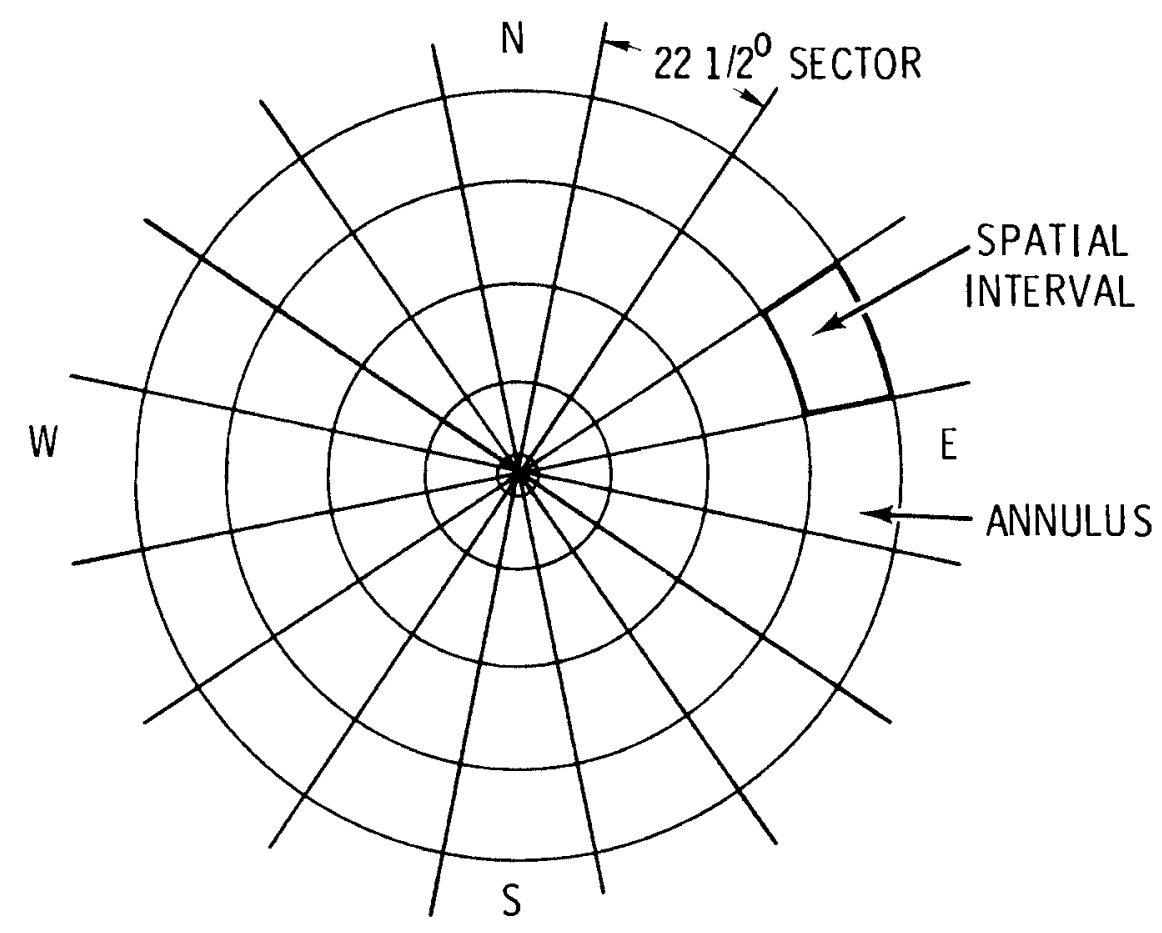

(FACILITY AT CENTER OF GRID)

FIGURE 4.0-1 Population Dose Grid System Definition

within the spatial interval is then calculated as the product of the individual dose and the population present in the spatial interval.

$$
P_{i}=D_{i} P_{i}
$$

where:

$\mathrm{P}_{\mathrm{i}} \bullet$ population dose within spatial interval $i$, man-rem

$D_{i}$ - dose to the average individual within spatial interval $i$, rem $p_{i}$ - population within spatial interval $i$, persons.

The total population dose is then calculated as the sum over all spatial intervals

$$
P=\sum_{i=1}^{N_{i}} \quad P_{i}
$$


where $P$ is the total population dose received in the vicinity of the site.

\subsection{ATMOSPHERIC TRANSPORT AND DIFFUSION}

The models recommended for atmospheric dispersion are taken mainly from information provided in USNRC (1977b) and IAEA (1980) with minor modifications from USNRC (1975).

The downwind transport of material released to the atmosphere is described by a straight-line Gaussian plume model. This model is applicable to sites having relatively flat terrain. Sites with marked terrain variation such as valleys, sea coasts or mountains may be poorly represented by the straight-line Gaussian model presented here. For such sites, use of more sophisticated models may be warranted.

The annual average air concentration is calculated at each location of interest using the crosswind averaged Gaussian disperison model for a $22.5 \%$ wind sector as represented by the following equation (USNRC 1977b).

$$
\left(\bar{x} / Q^{\prime}\right)_{x i j k}=\frac{2.032 f_{d}^{f} i j k}{u_{i} \Sigma_{z x k} d_{x}} \exp \left[-h_{e}^{2} / 2 \Sigma_{z x k}^{2}\right]
$$

where:

$$
\begin{aligned}
& \left(\bar{x} / Q^{\prime}\right)_{x i j k} \bullet \text { annual average normalized air concentration at location } x \\
& u_{i} \text { - midpoint of windspeed class } i \text { at a height representative } \\
& f_{d} \bullet \text { fraction of material remaining in the plume after } \\
& \text { depletion in transit to location } x \text {, dimensionless } \\
& f_{i j k} \bullet \text { annual average joint frequency of occurrence of windspeed } \\
& (i) \text {, stability (k) and sector direction }(j) \text { for the site, } \\
& \text { dimensionless } \\
& \Sigma_{z x k} \bullet \text { crosswind vertical standard deviation of plume } \\
& \text { concentration at distance } x \text { and stability class } k, m
\end{aligned}
$$




$$
\begin{aligned}
& h_{e} \bullet \text { effective release height, } m \\
& d_{x} \bullet \begin{array}{l}
\text { distance from release point to midpoint of distance } \\
\text { interval } x, m
\end{array} \\
& 2.032 \bullet(2 / \pi) 1 / 216 / 2 \pi .
\end{aligned}
$$

Other terms are as previously defined. The vertical dispersion parameter, $\Sigma_{z \times k}$, includes a volumetric correction for releases within the building wake cavity when the release point is near ground level. For elevated releases the uncorrected dispersion factor $\sigma_{z x k}$ is used. The building wake correction is described in Section 4.1.3. Methods for estimation of the plume depletion factor, $f_{d}$, are discussed in Section 4.1.7.

The joint frequency values $\left(f_{i j k}\right)$ used in Equation 4.1-1 must be expressed as a fraction. The ususal representation for joint frequency values is percent. If percent values are used, the equation must include a correction factor of 0.01 . The joint frequency values are generally based on onsite meteorological station data collected for a period of at lease one calendar year. This data is processed to redistribute unkown (no measurement) and calm (no measurable wind speed or direction) observations into the data set.

The vertical standard deviation of plume concentration parameter, ' $2 \times k$, is evaluated as a function of atmospheric stability and downwind distance. The atmospheric stability influences the amount of dispersion during transport. Stable atmospheric conditions result in less dispersion and, hence, lower values of the dispersion parameters than for unstable conditions. The most widely used method for relating atmospheric stability to the vertical dispersion parameter is that of Pasquill as modified by Gifford (Slade 1968). This method defines six atmospheric stability categories labeled from $A$ for most unstable to $F$ for most stable. For each stability a curve of $\sigma_{z x k}$ as a function of distance is defined (referred to as Pasquil1-Gifford curves). The Nuclear Regulatory Commission also considers a very stable category, G (USNRC 1977b). Several equations have been developed for evaluation of $\sigma_{z x k}$ for each stability category (Eimulits and Konicek 1972, Turner 1969, Gifford 1976). Each of these calculational methods give similar results. However, the formulas of Eimultis and Konicek (1972) as presented in Sagendorf and Goll (1977) are recommended as being applicable to annual average concentration values. 
These formulas (and all other formulas) for $\sigma_{z x k}$ are limited in that they are based on data taken within a few $\mathrm{km}$ of the release point but are routinely extrapolated to large distances.

The effective release height, $h_{e}$, includes corrections for plume rise, downwash and terrain variation. The effective release height, $h_{e}$, is calculated as a function of distance, direction, windspeed and stability as:

$$
h_{e}=h_{s}+\Delta h_{s}-h_{t}
$$

where:

$h_{s}$ - elevation of release point above base elevation, $m$

$\Delta h_{s}$ - correction to release height due to plume rise and downwash, $m$

$h_{t}$ - effective terrain elevation at the location of interest, $m$.

Calculation of plume rise and downwash is described in Section 4.1 .2 and terrain elevation variation is described in Section 4.1.4. The distance and direction dependence of $h_{e}$ result from plume rise (distance) and terrain variation. The windspeed and stability dependence result from plume rise and downwash corrections.

For sites having significant terrain features (i.e., mountains or valleys), consideration should be given to use of variable trajectory or other models that will account for the specific features of the site.

\subsubsection{Plume Rise}

In determining the effective height of release for use in the atmospheric dispersion equation, the plume rise models presented here are used to account for momentum. This plume rise model can be used to describe releases from stacks when the released gases are at or near ambient conditions. The equations presented below are used to estimate plume rise when the effluent release point is greater than two times the height of adjacent solid structures (USNRC 1977b). When the release point is lower, no plume rise correction is applied and the effective release height is constant at the effluent release height (except for possible terrain elevation corrections). 
Plume rise due to momentum is described below by models recommended by Briggs (1969, 1975). A correction for downwash is included, as given by Gifford (1972).

For neutral and unstable conditions, plume rise is calculated by

$$
h_{m}=1.44\left(\frac{w_{o}}{u}\right)^{2 / 3}\left(\frac{d_{x}}{D}\right)^{1 / 3} \quad D
$$

where:

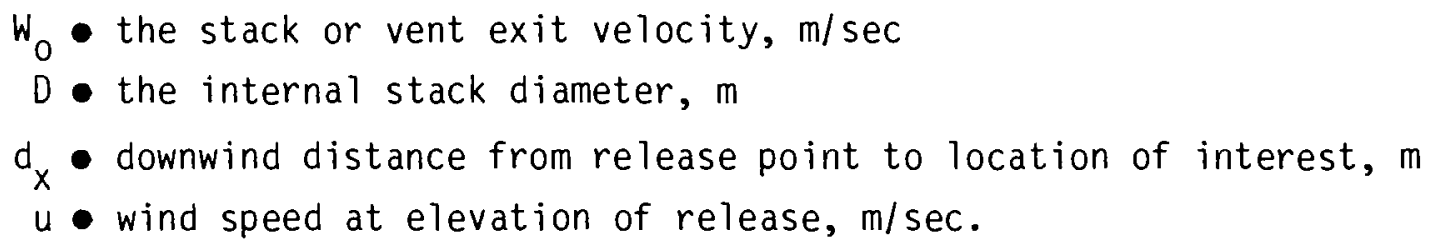

When the exit velocity $w_{0}$ is less than 1.5 times the wind speed $u$, a correction for stack downwash may be applied. This correction (Gifford 1972) is calculated as

$$
h_{d}=3\left(1.5-\frac{w_{0}}{u}\right) D_{e}
$$

where:

$$
\begin{aligned}
& h_{d} \bullet \text { the value to be substracted from } h_{m} \\
& D_{e} \bullet \text { the external stack diameter, } m .
\end{aligned}
$$

This correction should not be applied to stacks fitted with a disk extending. outward at lease one stack diameter, $D_{e}$. The result from Equation 4.1-3 after correction as necessary from downwash is compared with

$$
h_{m}=3\left(\frac{w_{0}}{u}\right) D
$$

and the smaller value of $h_{m}$ is used as the momentum plume rise correction. 
For stable conditions, the results from Equations 4.1-3 and 4.1-5 are compared with values calculated from the following two equations:

$$
\begin{aligned}
& h_{m}=4\left(\frac{F_{m}}{S}\right)^{1 / 4} \\
& h_{m}=1.5\left(\frac{F_{m}}{u}\right)^{1 / 3} s^{-1 / 6}
\end{aligned}
$$

where:

$$
F_{m}=\left(W_{0} D / 2\right)^{2}
$$

and:

$S$ - restoring acceleration per unit vertical displacement for adiabatic motion in the atmosphere $\left(\sec ^{-2}\right)$. For Pasquill E stability $S$ is $8.7 \times 10^{-4}$, for Pasquill $\mathrm{F}$ stability $S$ is $1.75 \times 10^{-3}$, and for Pasquill G stability $S$ is $2.45 \times 10^{-3}$.

The smallest value of $h_{m}$ from Equations $4.1-3,4.1-5,4.1-6$, and $4.1-7$ is used.

\subsubsection{Building Wake Correction Model}

Material released at ground level or from building vents or short stacks may be subject to enhanced dispersion due to the turbulent wake caused by air flow around the building. Models are designed to account for building wake through a correction factor for the Gaussian dispersion equation. The general way to handle building wake is to add a term to the plume size parameters to account for enhanced mixing in the wake of the building.

The method presented here is the U.S. Nuclear Regulatory Commission Regulatory Guide 1.111 model (USINRC 1977b) which was recommended by Sagendorf (1974). This model is to be applied to ground level releases only. The vertical plume spread term, $\Sigma_{z}$, of Equation $4.1-1$ is calculated as: 


$$
\Sigma_{z x k}=\left(\sigma_{z x k}^{2}+0.5 D_{z}^{2} / \pi\right)^{1 / 2} \leq \sigma_{z x k} \sqrt{3}
$$

where:

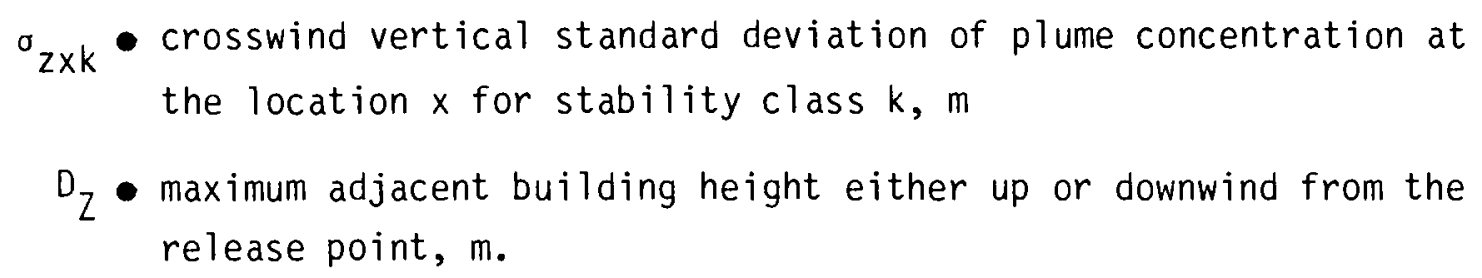

The term $\sigma_{z x k} \sqrt{3}$ represents the maximum allowed dispersion due to building wake effects.

\subsubsection{Terrain Elevation}

The effects of terrain elevation variation are considered by defining an effective elevation, $h_{t}$, at the midpoint of each spatial interval. This effective elevation is used to determine the effective plume height in Equation 4.1-2. The recommended method for defining values of $h_{t}$ is the horizontal plume model for terrain correction as described in Regulatory Guide 1.111 (USNRC 1977b). Using this method the value of $h_{t}$ is defined as the maximum terrain height between the release point and the exposure point. values supplied for $h_{t}$ should be positive or zero. This method is applicable to sites without major elevation variations such as mountains or valleys. For such sites the entire dispersion analysis may require more sophisticated site specific models than the staright-line Gaussian model.

\subsubsection{Dry Deposition}

The deposition of particulates and some gases is assumed to occur at all times during the year. This is the main process by which airborne contamination is transferred to the ground. The method recommended to estimate the ground contamination level is by use of effective deposition velocities. The deposition velocity relates air concentration to ground concentration by:

$$
G_{x j}^{n}=V_{d}^{n} \quad \sum_{i=1}^{N} Q^{\prime} \sum_{k=1}^{N_{s}}\left(\bar{x} / Q^{\prime}\right)_{x i j k}
$$


where:

$$
\begin{array}{cl}
G_{x j}^{n} & \text { - annual average deposition rate to ground at a distance } x \text { in } \\
& \text { sector } j \text { for radionuclide } n, C i / \mathrm{m}^{2} \mathrm{sec} \\
V_{d}^{n} & \text { - dry deposition velocity for radionuclide } \mathrm{n}, \mathrm{m} / \mathrm{sec} \\
Q_{n}^{\prime} & \text { - annual average release rate for radionuclide } n \text { corrected for } \\
& \text { radiological decay to distance } x, \mathrm{Ci} / \mathrm{sec} \\
\mathrm{N}_{\mathrm{s}} & \text { - number of stability classes considered, dimensionless } \\
N_{u} & \text { - number of windspeed classes considered, dimensionless } \\
\left(\bar{x} / Q^{\prime}\right)_{x i j k} & \text { - air concentration defined by Equation } 4.1-1 .
\end{array}
$$

As material deposits from the plume, the remaining activity in the plume is decreased. This decrease is described by use of plume depletion factors discussed in Section 4.1.6.

\subsubsection{Wet Deposition}

For most sites wet deposition is not expected to contribute significantly to terrestrial pathways (USNRC 1977c). However, for sites that have a rainy season corresponding to the grazing season, there may be a significant contribution from the forage-cow-milk pathway. An estimate of wet deposition can be made from the Engleman equation (Engleman 1968).

$$
\bar{x}=\bar{x}_{0} \exp (-\Omega t)
$$

where:

$$
\begin{aligned}
& \bar{x} \bullet \text { air concentration after wet deposition for a time } t \\
& \bar{x}_{0} \text { - initial air concentration } \\
& \Omega \bullet \text { washout coefficient, } \sec ^{-1} \\
& t \bullet \text { time since start of precipitation, sec. }
\end{aligned}
$$

The instantaneous rate of deposition may be determined by differentiation of the above equation. The rate of accumulation of material on the ground is then calculated based on a mass balance over the plume. 


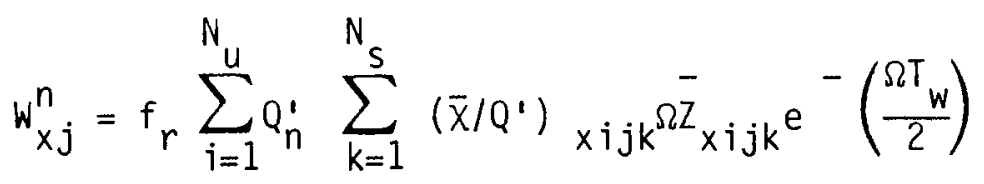

where:

$$
\begin{aligned}
& W_{x j}^{n} \quad-\text { annual average wet deposition rate at a distance } x \text { in } \\
& \text { sector } \mathrm{j} \text { for radionuclide } \mathrm{n}, \mathrm{Ci} / \mathrm{m}^{2} \mathrm{sec} \\
& f_{r} \quad \text { fraction of the time that rain occurs, dimensionless } \\
& Q_{n}^{\prime} \quad-\text { annual average release rate for radionuclide } n \text { corrected for } \\
& \text { radioactive decay in transit to location } \mathrm{x}, \mathrm{Ci} / \mathrm{sec} \\
& N_{S} \quad \text { number of stability classes, dimensionless } \\
& \mathrm{N}_{\mathrm{u}} \quad \text { - number of windspeed groups, dimensionless } \\
& \left(\bar{x} / Q^{2}\right)_{x i j k} \bullet \text { annual average normalized air concentration at distance } x \text { in } \\
& \text { sector } j \text { for windspeed } i \text { and stability class } k,\left(\mathrm{C} / \mathrm{m}^{3}\right) \text { per } \\
& (\mathrm{Ci} / \mathrm{sec}) \\
& \Omega \quad \text { - annual average washout coefficient, } \mathrm{sec}^{-1} \\
& \bar{Z}_{x i j k} \text { - effective plume thickness at distance } x \text { in sector } j \text { for } \\
& \text { windspeed } i \text { and stability class } k, m \\
& T_{W} \quad \text { average duration of a rain shower for the site, sec. }
\end{aligned}
$$

The deposition rate calculated by this equation represents the rate at the midpoint (in time) of a typical rain shower. A more conservative calculation (maximum rate) may be made by setting the shower period, $T_{W}$, to zero. This gives' the rate at the start of a shower.

The effective plume thickness, $\bar{Z}_{x i j k}$, represents an integral over the plume in the vertical direction and results from the mass balance approach. The following equation may be used to estimate the effective plume thickness for the Gaussian plume model (USNRC 1975).

$$
\bar{z}_{x i j k}=\left(\frac{\pi}{2}\right)^{1 / 2} \sum_{z x k} \exp \left[+\frac{h_{e}^{2}}{2 \sigma_{z x k}^{2}}\right]
$$


The exponential expression actually cancels with a similar term in the expression for $\bar{x} / Q^{\prime}$ (Equation 4.1-1). The above model for wet deposition is equivalent to that suggested in IAEA (1980) extended to cross-wind averaged dispersion.

Wet deposition will result in additional depletion of the plume. The plume depletion model defined in Section 4.1 .7 is based on dry deposition. It is suggested that the additional depletion be ignored even though this may enter a slight conservatism into the calculation.

The annual average washout coefficient may be estimated from the following equation.

$$
\Omega=\Omega_{1} P_{r} p
$$

where:

$\Omega_{1}$ - washout coefficient for an annual average precipitation rate of $1 \mathrm{~mm} / \mathrm{hr}, \mathrm{hr} / \mathrm{mm} \mathrm{sec}$

$\mathrm{P}_{r} \bullet$ annual average precipitation rate, $\mathrm{mm} / \mathrm{hr}$

p exponent to describe washout coefficient rate dependence on precipitation rate, dimensionless.

Slinn (1975) has suggested a linear relationship between the washout coefficient and precipitation rate $(p=1)$.

The methods given above for estimating wet deposition are limited by the varying scale of shower activity. The precipitation data is collected at one site but applied on a regional scale (i.e., $50 \mathrm{mi}$ radius). In using annual precipitation data it must be assumed that the observed precipitation rate is representative of the entire region.

\subsubsection{Plume Depletion}

Plume depletion due to wet and dry deposition processes results in reduced air concentrations at downwind locations. This reduction is partially counterbalanced by resuspension of deposited material. Horst (1979b) has recommended 
that plume depletion be ignored in calculation of downwind air concentrations to account for resuspension processes. The recommendations for the present study are as follows:

- For air exposure pathways (external and inhalation) plume depletion should be ignored to account for the resuspension contribution.

- For ground pathways (external and crop ingestion) the plume should be depleted to account for dry deposition.

Two methods are recommended for estimating plume depletion due to dry deposition: the surface depletion model of Horst (1979a) and the source depletion model presented in Regulatory Guide 1.111 (USNRC 1977b)

Regulatory Guide 1.111 considers plume depletion by using plume depletion correction factors (USNRC 1977b). These correction factors are based on dry deposition only because wet deposition is not usually significant for long term average concentrations. The factors ( $f_{d}$ in Equation 4.1-1) are based on measurements of deposition velocity as a function of windspeed (Markee 1967) and on a diffusion-deposition model presented by Pelletier and Zimbrick (1970). The calculated air concentration is multiplied by these correction factors to obtain the air concentration remaining after depletion. The correction factors are presented in the form of curves for each Pasquil1-Gifford stability category as a function of downwind distance for several effluent release heights.

The Horst source depletion model (Horst 1979a) uses a correction function, $P(x, z)$, to account for the change in the vertical concentration distribution due to deposition. This correction is applied in the basic expression for the depletion factor (Slade 1968) as follows:

$$
f_{d}=P(x, z) \exp \left\{-\int_{0}^{x} v_{d}^{n} D\left(x^{\prime}, z_{\star}, h_{e}\right) P\left(x^{\prime}, z_{\star}\right) d x^{\prime}\right\}
$$

where:

$f_{d}-$ fraction of material remaining airborne at downwind distance $x$, dimensionless 


$$
\begin{aligned}
& v_{d}^{n} \text { e effective deposition velocity for radionuclide } n \\
& \text { defined at reference height } z_{\star}, \mathrm{m} / \mathrm{sec} \\
& D\left(x^{\prime}, z_{\star}, h_{e}\right) \bullet \text { cross-wind integrated air concentration at downwind } \\
& \text { location } x^{\prime} \text { for plume elevation } h_{e} \text { and reference } \\
& \text { height } z_{\star}, \sec / \mathrm{m}^{2} \text { (defined below) } \\
& P(x, z) \text { - plume concentration correction function at downwind } \\
& \text { location } x \text { and elevation } z \text {, dimensionless (defined below) } \\
& x^{\prime} \text { - variable of integration, downwind distance, } m \\
& z_{\star} \text { - reference height for definition of the deposition } \\
& \text { velocity, } m \\
& h_{e}-\text { effect height of the plume centerline, } m
\end{aligned}
$$

The crosswind integrated air concentration for unit source strength is defined as follows (Horst 1979a).

$$
D\left(x, z, h_{e}\right)=\frac{1}{\sqrt{2 \pi} \bar{u}_{i} \sigma_{z}}\left\{\exp \left[-\frac{\left(h_{e}-z\right)^{2}}{2 \sigma_{z x k}^{2}}\right]+\exp \left[-\frac{\left(h_{e}+z\right)^{2}}{2 \sigma_{z x k}^{2}}\right]\right\}
$$

where all terms are as previously defined. Note that $z$ is normally set to zero when exposures at ground level are desired. The evaluation of $P\left(x^{\prime}, z_{\star}\right)$ is as follows:

$$
P\left(x, z_{\star}\right)=\left[1+\frac{v_{d}^{n}}{\left(H_{x^{-z_{\star}}}\right)} \int_{z_{\star}}^{H_{x}}\left(\frac{1}{\bar{u}_{i}} \sqrt{\frac{2}{\pi}} \int_{x_{1}}^{x_{2}} \frac{d x^{\prime}}{\sigma_{z x^{\prime} k}}\right) d z\right]^{-1}
$$

where:

$$
\begin{aligned}
& x_{1} \bullet \text { the distance at which } \sigma_{z x k}=\sqrt{\frac{\pi}{2}} z_{\star}, m \\
& x_{2} \bullet \text { the distance at which } \sigma_{z x k}=\sqrt{\frac{\pi}{2}} z, m \\
& H_{x} \bullet \text { an effective mixing depth calculated } \\
& \text { as } H_{x}=\sqrt{\pi / 2} \sigma_{z x k}
\end{aligned}
$$


and other terms are as previously defined. The disadvantage to using the equations of Horst is that numerical solutions are required.

\subsubsection{Mixing Depth}

The recommended method to account for effects of the mixing layer depth is to limit the maximum value of the vertical dispersion parameter, $\Sigma_{z x k}$ to $80 \%$ of the average annual mixing layer depth, $L$.

$$
\Sigma_{z \times k} \leq 0.8 \mathrm{~L}
$$

where:

L average annual mixing layer depth for the site, m.

The value of $80 \%$ is based on the concentration under uniform distribution of material in the mixing layer. To determine the uniform mixing concentration the denominator of Equation $4.1-1$ is modified by setting

$$
\Sigma_{z \times k}=0.8 \mathrm{~L}
$$

and the exponential term is set to 1.0. This method for limiting the vertical expansion of the plume is similar to that of Turner (1969).

The data presented by Holzworth (1972) can be used to estimate the mixing layer depth. Values from Holzworth for morning and afternoon mixing layer are used as follows:

$$
\frac{1}{L}=\frac{1}{2}\left(\frac{1}{L_{A M}}+\frac{1}{L_{P M}}\right)
$$

where:

$L_{A M}$ - mean annual morning mixing depth, m
$L_{P M}$ - mean annual afternoon mixing depth, m.

An alternate method is to define values of mixing depth for each Pasquill-Gifford stability class (Busse and Zimmerman 1973) as follows: 


$\begin{array}{cl}\begin{array}{ll}\text { Pasquill-Gifford } \\ \text { Stability Class }\end{array} & \frac{\text { Mixing Depth }}{A} \\ B, C & 1.5 \times L_{P m} \\ D \text { (day) } & L_{P M} \\ D \text { (night) } & \left(L_{P M}+L_{A M}\right) / 2 \\ E, F, G & L_{A M}\end{array}$

\subsection{WATERBORNE TRANSPORT}

Radionuclides released to surface waters and groundwater may result in exposures via several pathways. To estimate the exposure, it is necessary to know the water contamination level at usage locations. Actual environmental monitoring data may be the best method for determining water contamination levels, provided information on specific radionuclides is included. In the absence of adequate monitoring data an estimate of waterborne transport and dilution between the release point and each usage location must be made.

As mentioned in Section 3.2, the modeling of waterborne transport is very site specific and should be done on a case-by-case basis. Recommendation of specific models is not practical except for dilution in a large smooth flowing river. Release to a large river will result in a uniform water concentration at downstream distances of several times the river width. Under these conditions the water dilution factor can be estimated by

$$
D_{\ell}=\frac{1}{F_{r}}
$$

where:

$$
\begin{aligned}
& D_{\ell} \bullet \text { water dilution factor at location } \ell, \mathrm{sec} / \mathrm{m}^{3} \\
& \mathrm{~F}_{r} \bullet \text { river flow rate, } \mathrm{m}^{3} / \mathrm{sec} \text {. }
\end{aligned}
$$

The dilution factor may be multiplied by the annual average release rate in $\mathrm{C} i /$ sec to give the annual average water concentration: 


$$
C_{\ell}^{n}=Q_{W n}^{\prime} D_{l}
$$

where:

$$
\begin{aligned}
& C_{\ell}^{n}-\text { annual average water concentration at usage location } \ell \text { for } \\
& \text { radionuclide } n, C i / m^{3} \\
& Q_{w n}^{\prime}-\text { annual average release rate to the river for radionuclide } n \text {, } \\
& \quad C i / s e c .
\end{aligned}
$$

\subsection{EXPOSURE PATHWAYS}

Exposure pathway models relating environmental contamination levels to human consumption are described in this section. The discussion of recommended models follow the same classifications as used in the model review section (Section 3.0):

- exposure to airborne plumes

- aquatic pathways

- terrestrial pathways

- direct exposure from contained sources.

The term "dose" is used in this report to mean "dose equivalent."

\subsubsection{Exposure to Airborne Plumes}

Pathways of interest in this category are:

- external radiation from airborne material

- uptake from inhalation of plume.

The exposure received from these pathways is dependent on the air concentration at the location of interest. The air concentration for these pathways is calculated as the undepleted air concentration for Equation 4.1-1 with the depletion factor, $F_{d}$, set to unity. Plume depletion is ignored to compensate for the contribution from resuspension.

The external plume exposure pathway is generally not important because the dose received from inhalation outweighs the external radiation dose. An exception is exposure to noble gases which are not retained significantly in the lungs. Another situation where external exposure may be signficant is for gamma emitting radionuclides released from elevated sources. When the plume is high above the ground, the ground-level concentration may be very small but 
the gamma radiation will still irradiate persons at ground level. These limitations have been considered in selecting the models recommended for the external exposure pathway.

A summary of the methods recommended for calculation of external dose is provided by the following general statements.

- For ground-level releases, external exposure to the plume may be ignored for radionuclides other than noble gases.

- For elevated releases (i.e., from stacks at 80 meters or higher), external exposure should be included for all radionuclides using a finite plume correction.

- A semi-infinite plume calculation may be used for noble gas release below 50 meters.

When the semi-infinite plume model is used to calculate external dose, the plume is assumed to be of uniform concentration equal to the groundlevel annual average air concentration. The external dose to an individual at a downwind distance $x$ in sector $j$ is given by

$D_{x j}^{e}=0.25 \sum_{n=1}^{N_{n}} \sum_{\ell=1}^{N_{p}} E_{r n \ell} e^{-\mu_{\ell}^{\prime} d} \sum_{k=1}^{N_{s}} \sum_{j=1}^{N_{u}} Q_{n}^{\prime}\left(\bar{x} / Q^{\prime}\right)_{x i j k}$

where:

$D_{x j}^{e} \bullet$ external dose to an individual at downwind distance $x$ in sector $j, r e m / y r$

$Q_{n}^{\prime} \bullet$ annual average release rate for radionuclide $n$ corrected for decay in transit to location $\mathrm{x}, \mathrm{C} i /$ year

$E_{\gamma n \ell}$ - total gamma energy emitted by radionuclide $n$ in energy group $\ell$, Mev/dis

$\mu_{\ell}^{\prime}$ - linear total attenuation coefficient for tissue for photons in energy group $\ell, \mathrm{cm}^{-1}$,

d - depth in tissue of exposure point, $\mathrm{cm}$ (set to $5 \mathrm{~cm}$ for total body dose) 


$$
\begin{aligned}
& \left(\bar{x} / Q^{\prime}\right)_{x i j k} \bullet \text { annual average normalized air concentration at downwind } \\
& N_{n} \bullet \text { number of radionuclides } \\
& N_{p} \bullet \text { number of photon energy groups } \\
& N_{S} \bullet \text { number of stabilities } \\
& \mathrm{N}_{\mathrm{u}} \bullet \text { number of windspeed groups } \\
& 0.25 \text { - unit conversion constant (Slade 1968, p. 339) } \\
& \left(\frac{\text { rad }}{\text { year }}\right) \operatorname{per}\left(\frac{\operatorname{MeV} C i}{m^{3} \text { dis }}\right)
\end{aligned}
$$

When the finite plume model is to be used, the dose equation must include the volume integral of dose for each windspeed, stability and photon energy. The evaluation must be made at each location of interest using the effective release height at that location. The calculational effort can be reduced by use of precalculated dose rate conversion factors that replace the product $0.25\left(\bar{x} / Q^{\prime}\right)_{x i j k}$ in the above equation. The dose rate factor can be represented as

$$
\begin{aligned}
& \operatorname{DRF}_{x i j k}=\left(\frac{2}{\pi}\right)^{1 / 2}\left[\frac{16 f_{i j k}}{4_{\pi} u_{i}}\right] \int_{x_{1}}^{x_{2}} \quad \int_{z_{1}}^{z_{2}} \exp \left[\frac{\left(z-h_{e}\right)^{2} / 2_{z x k}^{\sigma 2}}{\sigma_{z x k}}\right] \\
& \int_{y_{1}}^{y_{2}} \frac{B\left({ }^{\mu} \ell r\right) \exp \left(-{ }^{\mu} \ell r\right) K}{4 \pi r^{2}} \ell d x d y d z
\end{aligned}
$$

where:

$$
\begin{aligned}
& D_{x i j k}^{\ell}-\begin{array}{l}
\text { external dose rate factor for photon group } \ell \text { at downwind } \\
\text { distance } x \text { in sector } j \text { for windspeed class } i \text { and stability } k
\end{array} \\
& f_{i j k} \text { - annual average joint frequency of occurance of windspeed } i, \\
& \text { stability } k \text { and sector direction } j \text { for the site, dimensionless }
\end{aligned}
$$




$$
\begin{aligned}
\sigma_{z x k} & \text { vertical crosswind averaged standard deviation of plume } \\
& \text { concentration at distance } x \text { for stability } k, m \\
h_{e} & \text { effective plume centerline height at downwind distance } x \text { in } \\
& \text { sector } j, m \\
B\left(u_{\ell} r\right) & \text { photon dose buildup factor for air, dimensionless } \\
\mu_{\ell} & \text { total linear attenuation coefficient in air for photons in } \\
& \text { energy group } \ell, m^{-1} \\
r & \text { distance from integration volume element dxdydz to the exposure } \\
& \text { point, } m \\
k_{\ell} & \text { dose conversion factor for photons in energy group } \ell,\left(r a d m^{2}\right) \\
& /(C i \text { sec }) \text { per MeV/disintegration }
\end{aligned}
$$

The constant $K_{\ell}$ is:

$$
K_{\ell}=\frac{3.70 \times 10^{10} \frac{\mathrm{dis}}{\mathrm{Ci} \mathrm{sec}} 1.60 \times 10^{-6} \frac{\mathrm{erg}}{\mathrm{MeV}} 10^{-4} \frac{\mathrm{m}^{2}}{\mathrm{~cm}^{2}}\left(\frac{\mu \mathrm{a}}{\mathrm{p}}\right)_{\ell}}{100 \frac{\mathrm{ergs}}{\mathrm{grad}}}=0.592\left(\frac{\mu \mathrm{a}}{\mathrm{p}}\right)_{\ell}
$$

where:

$$
\begin{aligned}
& \left(\frac{\mu a}{p}\right)_{\ell} \text { - mass absorption coefficient, } \mathrm{cm}^{2} / g \text { in tissue for average gamma } \\
& \text { energy of energy group } \ell .
\end{aligned}
$$

Evaluation of the dose rate factor requires a computer. Several computer programs have been written to evaluate the dose rate factors in the above form or slightly modified forms (Strenge and Watson 1973; Cooper 1972; USNRC 1977c). The most easy of these to apply is the subroutine presented in Regulatory Guide 1.109 (USNRC 1977c). This subroutine allows evaluation of the dose rate factor integral $I_{x i k}{ }_{x i k}$ related to the dose rate factor of Equation $4.3-2$ by:

$$
D_{x i j k}^{\ell}=0.29 \frac{\mu_{a}^{\ell}}{u_{i} \times \Delta \theta} I_{x i k}^{\ell}
$$


where:

$I_{x i k}$ - dose rate integral for energy group $\&$ at a distance $x$ at wind speed $i$ and stability $k$, dimensionless

$\mu \ell$ - energy absorption coefficient for air for energy group $\ell, \mathrm{m}^{-1}$

$\Delta \theta$ - sector width in radians, $2 \pi / 16$

$0.29=1.11 \frac{3.7 \times 10^{10}\left(\frac{\mathrm{dis}}{\mathrm{ci}-\mathrm{sec}}\right) 1.6 \times 10^{-6}\left(\frac{\mathrm{erg}}{\mathrm{g} r \mathrm{rd}}\right)}{1293 \frac{\mathrm{g}}{\mathrm{m}^{3}} 100\left(\frac{\mathrm{erg}}{\mathrm{g}-\mathrm{rad}}\right)}$

where:

1.11 - average ratio of tissue to air energy absorption coefficients

1293 - air density, $\mathrm{g} / \mathrm{m}^{3}$

and other terms are as previously defined.

The limits of integration in the crosswind direction are the sector boundaries. The sector-averaged Gaussian plume model is intended to account for averaging effects of plume meander within the sector over extended times. The process of averaging the plume activity over the sector width is only appropriate when the sector width is considerably larger than the $\gamma$-ray mean free path length and the horizontal dispersion parameter, $\gamma_{y}$ (Lahti et al. 1981). This condition is met at large distances. However, at near distance $(<2 \mathrm{~km})$ the sector-averaged model can result in an overestimate of the finite plume dose rate factor. The over estimate is not considered to be serious because of a compensating underestimate. Over an extended period of time the wind will blow in most directions for a significant time. The contribution to external exposure in a given sector from material in an adjacent sector is not considered in the dose rate integrals. The neglected contributions are approximately compensated for by the over estimate in the cross wind averaging process.

The inhalation exposure pathway is significant for all radionuclides except noble gases. The inhalation dose is calculated from the undepleted ground level air concentration by the following equation 


$$
D_{x j}^{i}=D F_{i 0}^{n} \sum_{n=1}^{N} \sum_{k=1}^{N_{n}} \sum_{i=1}^{N_{u}} Q_{n}^{\prime}\left(\bar{x} / Q^{\prime}\right)_{x i j k}
$$

where:

$$
\begin{aligned}
& D_{x j}^{i} \text { - inhalation dose to an individual at downwind distance } x \text { in } \\
& \text { sector } j \text {, rem/year } \\
& \mathrm{DF}_{i 0}^{\mathrm{n}} \text { - inhalation dose commitment factor for radionuclide } n \text { and organ } 0, \\
& \quad \text { rem/year per } \mathrm{C} / \mathrm{m} \mathrm{m}^{3}
\end{aligned}
$$

and other terms are as previously defined. The inhalation dose commitment factors represent the dose received over a defined time period (i.e., 50 years) resulting from inhalation at a constant rate for one year. Dose commitment factors for chronic inhalation have been calculated by Hoenes and Soldat (1977). Calculation of dose commitment factors is discussed in Section 4.4.2.

\subsubsection{Aquatic Pathways}

Pathways of interest related to aquatic contamination include:

- external exposure pathways (swimming, boating and shoreline activities)

- ingestion of drinking water

- ingestion of aquatic foods

In addition to these pathways the use of contaminated water to irrigate food crops may result in ingestion of contaminated crops. This pathway is considered in the next section (Terrestrial Pathways).

The external exposure pathway for contaminated shoreline is dependent on the buildup of radionuclides in shoreline sediments. Modeling sediment load, transport and radionuclide buildup is a complex problem. For the present application, a simplified model of Soldat et al. (1974) is recommended. The model assumes a constant water concentration for the duration of release (1 year for this study). The deposition rate to shoreline sediments is assumed to be proportional to water concentration and removal from the sediments is only by radioactive decay. This is described by: 


$$
\frac{d C_{n s}}{d}=k C_{\ell}^{n}-C_{n s} \lambda_{n}
$$

where:

$$
\begin{aligned}
C_{n s} & \bullet \text { concentration of radionuclide } n \text { in sediments, } c i / m \\
C_{\ell}^{n} & - \text { concentration of radionuclide } n \text { in water at location } \ell, C i / \ell \\
k & \bullet \text { proportionality constant for transfer from water to sediment } \\
& \ell \cdot m^{-2} y^{-1} \\
\lambda_{n} & \bullet \text { radiological decay constant for radionuclide } n, y^{-1}
\end{aligned}
$$

The value of the parameter $K$ is reported by Napier et a1. (1980) to be $25,300 \mathrm{em}^{-2} \mathrm{y}^{-1}$. This value was derived from the original value of Soldat (1974) of 100 for an expression using the radiological half-life in units of days. Three significant figures are retained in the value 25,300 to be compatible with the original value of 100 even though the number is only an order of magnitude estimate. The orginal value of $K$ was derived from measured water and sediment concentrations collected over a period of years in the Columbia River between Richland, Washington and the river mouth in Tillamock Bay, oregon. Equation 4.3-6 can be solved for $c_{n s}$ as a function of time. The resulting function for $C_{n s}$ can be solved for a one year period to give the following expression for dose rate due to shoreline exposure at one year.

$$
D_{\ell_{S}}=\operatorname{KWU} \sum_{S=1}^{N_{n}} c_{\ell}^{n} D_{p}^{n} \frac{1-e^{-\lambda n T}}{\lambda_{n}}
$$

where:

$$
\begin{aligned}
& D_{\ell_{S}} \text { - dose received during the year from exposure to contaminated shore- } \\
& \text { line sediment at location } \ell \text {, rem/year } \\
& W \text { - shoreline width factor to account for the finite width of the shore } \\
& \text { relative to an infinite plane source, dimensionless } \\
& U_{S} \text { - usage parameter giving the hours per year of exposure to shoreline } \\
& \text { activities, hours/year }
\end{aligned}
$$


$D_{p}^{n}$ - external dose rate conversion factor for radionuclide $n$ and for exposure to an infinite plane source, rem/hour per $\mathrm{ci} / \mathrm{m}^{2}$

$T_{1}$ - duration of exposure equal to one year, yr

and other terms are as previously defined. This expression is suggested by Napier et a . (1980) and USNRC (1977c) for calculation of the shoreline sediment dose. This expression in effect uses the concentration at the end of the year to determine the dose during the entire year. The resulting dose is thus maximized. A more correct method would be to integrate the dose rate Equation (4.3-7) over a one-year period. However, the value of parameters in the equation are only accurate to an order of magnitude so that the given expression is quite adequate.

The shore width factor $W$ accounts for the actual geometry of a river bank or other beach with respect to the infinite plane geometry used for the dose rate conversion factor, $D_{p}$. Values suggested for the shore width factors are presented in Table 4.3-1 as recommended by Napier et al. (1980).

TABLE 4.3-1. Shore width Factors

Exposure Situation Shore Width Factor (W)

Discharge Canal Bank 0.1

River Shoreline 0.2

Lake Shore 0.3

Nominal Ocean Site 0.5

Tidal Basin $\quad 1.0$

External exposures from boating and swimming are represented by partial or complete submersion in the contaminated water. The dose to individuals swimming can be calculated by assumming the water to be an infinite medium with respect to the range of the emitted radiations. The dose to people boating is assumed to be half that to the swimmers. The following equations are recommended for estimating the annual dose from swimming and boating activities. 


$$
D_{\ell s W}=U_{S W} \sum_{n=1}^{N_{n}} c_{\ell}^{n} \quad D_{w}^{n}
$$

and

$$
D_{\ell b}=0.5 U_{b} \quad \sum_{n=1}^{N} \quad c_{\ell}^{n} D_{w}^{n}
$$

where:

$$
\begin{aligned}
& D_{\ell S W} \bullet \text { annual external dose from swimming in contaminated water at } \\
& \text { location } \ell \text {, rem/year } \\
& D_{\ell b} \text { - annual external dose from boating on contaminated water at location } \\
& \ell \text {, rem/year } \\
& U_{\text {SW }} \text { - usage factor for swimming activities, hours/year } \\
& U_{b} \text { - usage factor for boating activities, hours/year } \\
& D_{W}^{n} \bullet \text { dose rate conversion factor for submersion in an infinite water } \\
& \text { medium for radionuclide } n \text {, rem/hour per } \mathrm{C} i / \ell \\
& C_{\ell}^{n} \text { - annual average water concentration for radionuclide } n \text { at } \\
& \text { location } \ell, \mathrm{Ci} / \ell \text {. }
\end{aligned}
$$

The factor of 0.5 in the boating dose equation accounts for the fact that the individuals are exposed to a half-infinite source. The usage parameters $U_{S W}$ and $U_{b}$ may also be dependent on location $(l)$ even though this dependence is not indicated in the above equations.

Use of contaminated water as a source of drinking water will result in exposure via ingestion. The actual uptake of radionuclides by humans is subject to purification treatment and consumption rates. The ingestion dose from this pathway can be estimated from the following expression.

$$
D_{\ell d o}=U_{d} \sum_{n=1}^{N_{n}} P_{\ell}^{n} C_{\ell}^{n} D F_{0}^{n}
$$


where:

$$
\begin{aligned}
& D_{\ell d o} \text { - ingestion dose commitment to an organ o from the arinking } \\
& U_{d} \bullet \text { drinking water usage parameter, } \ell / \text { year } \\
& p^{n} \text { - water treatment } p l a n t \text { purification factor for location } \ell \text { and } \\
& \text { radionuclide } n \text {, dimensioniess } \\
& \mathrm{DF}_{0}^{n} \text { - ingestion dose commitment factor for organ } 0 \text { and } \\
& \text { radionuclide } n \text {, rem/ year per } C_{i} \text { ingested. }
\end{aligned}
$$

Values used for the water treatment plant purification factors depend on the type of treatment (if any) used. Napier et al. (1980) have reported values for use with the alum-floc process based on data collected at Richland and Pasco, Washington on the Columbia River.

Ingestion of aquatic foods harvested from contaminated water will result in human exposure. The activity of radionuclides in aquatic foods is generally assumed to be proportional to the water concentration. The proportionality constant is based on the equillibrium concentration ratio and referred to as a bioaccumulation factor. The dose from ingestion of an aquatic food is calculated as:

$$
D_{\ell a 0}=U_{a} \sum_{n=1}^{N_{n}} R_{a}^{n} \quad C_{\ell}^{n} B_{a}^{n} D F_{0}^{n}
$$

where:

$$
\begin{aligned}
& D_{\ell a 0} \text { - ingestion dose commitment to an organ o from the aquatic food } \\
& \text { pathway at location } \ell \text {, rem/year per } \mathrm{C}_{i} \text { ingested } \\
& U_{\mathrm{a}} \text { - } \text { aquatic food usage parameter, } \mathrm{Kg} / \text { year } \\
& \mathrm{R}_{\mathrm{a}} \text { - fraction of activity of radionuclide } \mathrm{n} \text { retained in edible } \\
& \text { portions of aquatic food during harvest and preparation for } \\
& \text { consumption, dimensionless }
\end{aligned}
$$


$\mathrm{B}_{\mathrm{a}}$ - bioaccumulation factor for radionuclide $\mathrm{n}$ for aquatic food $\mathrm{Ci} / \mathrm{kg}$ per $\mathrm{Ci} / \ell$

and other terms are as previously defined. The above equation must be evaluated for each aquatic food type of interest, i.e., fish, clams, crabs, etc. Bioaccumulation factors have been tabulated by NRC (1977c) and Napier et al. (1980).

\subsubsection{Terrestrial Pathways}

Contamination reaching the terrestrial environment can result in human exposure through the following pathways:

- external exposure to contaminated ground

- ingestion of contaminated crops

- ingestion of contaminated animal products

The contamination of ingestion pathways may result from either airborne depositions onto farmland or waterborne deposition via irrigation or use of contaminated animal drinking water. The inhalation pathway from resuspension of grouna contamination was disucssed in Section 4.3.1 and is not included here. The terrestrial pathways will be discussed in the order listed above.

All of the terrestrial pathways are dependent on the contamination level. The concentration of radionuclides on the ground is defined in units of activity per area $\left(\mathrm{Ci} / \mathrm{m}^{2}\right)$. For deposition from airborne plumes the grouna deposition rate is calculated as:

$$
d_{a}^{n}=Q_{n}^{\prime}\left(\bar{x} / Q^{\prime}\right)_{x i j k} V_{d}^{n}+w_{x j}^{n}
$$

where:

$$
\begin{aligned}
& d_{a}^{n} \text { - annual average deposition rate from air for } \\
& \text { radionuclide } n, C i / m^{2} \text { per year } \\
& Q_{n}^{\prime} \text { - annual average release rate for radionuclide } n, C i / s e c
\end{aligned}
$$




$$
\begin{aligned}
& \left(\bar{x} / Q^{\prime}\right)_{x i j k} \bullet \text { annual average normalized air concentration at distance } \\
& V_{d}^{n} \bullet \text { dry deposition velocity for radionuclide } n, m / s e c \\
& W_{x j}^{n} \text { - annual average wet deposition rate at a distance } x \\
& \text { in sector } j \text { for radionuclide } n, \mathrm{Ci} / \mathrm{m}^{2} \mathrm{sec} \text {. }
\end{aligned}
$$

For irrigation deposition the deposition rate to farmland is calculated as:

$$
d_{w}^{n}=c_{l}^{n} \quad I
$$

where:

$$
\begin{aligned}
& d_{w}^{n} \text { - annual average deposition rate from irrigation water, } \mathrm{Ci} / \mathrm{m}^{2} \text { per year } \\
& C_{\ell}^{n} \text { - annual average water concentration at location } \& \text { for radionuclide } n, \\
& \quad \mathrm{Ci} / \ell \\
& \text { I - annual average irrigation rate, } \ell / \mathrm{m}^{2} \text { per year. }
\end{aligned}
$$

The total deposition rate is the sum of the air deposition rate and the irrigation deposition rate. For a given location (distance $x$ and sector $k$ ) a corresponding irrigation water usage location $\ell$ must be defined. An alternative approach (Napier et al. 1980) is to use site average values for air and water concentrations. Then the deposition rate represents a site average and is applied to all locations and terrestrial pathways. The resulting doses are appropriate for estimating average exposures of the population. In a similar manner a "maximally exposed individual" dose can be estimated by using maximum values for air and water concentrations. In the equations to follow the exposure location will sometimes be omitted from the expressions (as for $d^{n}$ and $d_{w}$ above). The equations are defined to give dose to an individual (as for the airborne plume and aquatic pathway equations). 
The ground concentration during the year is given by:

$$
c_{s}^{n}=\left(d_{w}^{n}+d_{d}^{n}\right)\left[\frac{1-e^{-\lambda} n^{t}}{\lambda_{n}}\right]
$$

where:

$$
\begin{aligned}
& C_{s}^{n} \bullet \text { ground concentration for radionuclide } n, C i / m^{2} \\
& \lambda_{n} \text { - radiological decay constant for radionuclide } n, y r^{-1} \\
& t \bullet \text { time since start of deposition, year }
\end{aligned}
$$

and other terms are as defined above. This equation is applicable during the period of deposition (year of release). Times beyond the first year are not of interest for the present study because the exposure of interest is that received during the first year.

The external exposure from contaminated ground is generally based on tne ground concentration at the end of the first year. Using this maximum ground concentration gives good results for short-lived radionuclides (<100 aays) and overestimates the external aose by no more than a factor of two for long-lived radionuclicies. The external dose is given by the following equation:

$$
D_{g}^{e}=U_{g} \sum_{n=1}^{N_{n}} D_{p}^{n} c_{s}^{n}
$$

where:

$$
\begin{aligned}
& D_{g}^{e} \text { - external dose from ground contamination received ouring the } \\
& \text { year of release, rem/year } \\
& U_{g} \text { - usage parameter for ground exposure, hours per year } \\
& D_{p}^{n} \text { - external dose rate conversion factor for radionuclide } n \text { for an } \\
& \text { infinite } \mathrm{plane} \text { source, rem } / \mathrm{hr} \text { per } \mathrm{Ci} / \mathrm{m}^{2} \\
& \mathrm{~N}_{n} \text { - number of radionuclides. }
\end{aligned}
$$


As mentioned above there is no location index on the external dose symbol $D_{G}$ as this parameter may be calculated for either a site average or for a particular location. For farmlanas the ground concentration may nave contributions from both air and water deposition. For non-farm lands only air deposition should be considered.

The dose received from ingestion of contaminated crops depends on radionuclide deposition rates, plant uptake and other parameters related to consumption. Above ground food crops may be contaminated by direct deposition and root uptake. Root crops are only contaminated by root uptake. The concentration reaching the edible portions of the plant via root uptake is given by the following equation:

$$
C_{r}^{n}=\frac{C_{s}^{n} B_{n v}}{p}
$$

where:

$$
\begin{aligned}
& C_{r}^{n} \text { - concentration of radionuclide } n \text { in plants from root uptake, } \\
& \mathrm{Ci} / \mathrm{kg} \\
& C_{s}^{n} \bullet \text { ground concentration of radionuclide } n \text { as given by } \\
& \text { Equation 4.3-14 evaluated at the end of the year, } \mathrm{Ci} / \mathrm{m}^{2} \\
& B_{n v} \text { - the concentration ratio for plant uptake of radionuclide } n \\
& \text { for plant type } v, \mathrm{Ci} / \mathrm{kg} \text { (wet weight) per } \mathrm{Ci} / \mathrm{kg} \text { (ary soil) } \\
& P \text { - the soil "surface density", } \mathrm{kg}(\operatorname{ary} \text { soil)/m². }
\end{aligned}
$$

A value of $224 \mathrm{~kg} / \mathrm{m}^{2}$ for $P$ has been suggested by Napier et al. (1980). Above ground crops are subject to direct deposition as determined by the following equation.

$$
c_{d}^{n}=\left(d_{a}^{n}+d_{w}^{n}\right) r T_{v} \frac{1-e^{-\lambda_{E}^{n} T_{e}}}{\lambda_{E}^{n} r_{v}}
$$


where:

$$
\begin{aligned}
& C_{d}^{n} \bullet \text { plant concentration at the time of harvest, } C i / k g \\
& r \bullet \text { the fraction of direct deposition retainea on plant toilage, } \\
& \text { dimensionless } \\
& T_{v} \bullet \begin{array}{l}
\text { a factor to describe translocation of contamination to } \\
\text { edible parts of the plant, dimensionless }
\end{array} \\
& \lambda_{E}^{n} \bullet \text { the effective environmental removal constant for plants, } \\
& \text { years }{ }^{-1} \cdot \lambda_{E}=\lambda_{n}+\lambda_{E w}: \text { where } \lambda_{E w} \text { is the weathering constant, } \\
& \text { years }{ }^{-1} \text {. } \\
& T_{e} \text { - time of crop exposure above ground during one growing } \\
& \text { season, yr } \\
& Y_{v} \bullet \text { the plant yield, kg (wet weight) } / \mathrm{m}^{2} .
\end{aligned}
$$

The retention fraction, $r$, may be assumed to be equal for air and irrigation deposition. A value of 0.25 has been suggested for $r$ by Napier et al. (1980). Suggested values for the translocation factor, $T_{v}$, are 1.0 for leafy vegetables and fresh forage, and 0.1 for all other produce including grain. The effective environmental removal constant is generally calculated for a weathering half time of 14 days.

The total concentration of a radionuclide $n$ in a plant type $v$ is represented as $c_{v}^{n}$. The total is calculated as the sum of the concentrations from root uptake, $c_{r}^{n}$ and direct deposition, $c_{d}^{n}$.

Radioactive decay between the time of harvest and consumption is estimated for simply decaying radionuclides by the following equation.

$$
C_{v}^{n} \text { (consumption) }=C_{v}^{n} \text { (harvest) } e^{-\lambda n^{t} h}
$$

where $t_{h}$ is the holdup time between harvest and consumption and other terms are as previously defined. 
Contamination of animal products can result from animal intake of contaminated drinking water or feed. The concentration in animal products is calculated using transfer coefficients as indicated in the following equation.

$$
c_{a}^{n}=s_{a}^{n}\left(c_{F}^{n} Q_{F}+c_{l}^{n} Q_{a w}\right)
$$

where:

$$
\begin{aligned}
& C_{a}^{n} \cdot \text { concentration of radionuclide } n \text { in animal product, } C i / k g \\
& S_{a}^{n} \text { - the transfer coefficient of radionuclide } n \text { from daily intake of }
\end{aligned}
$$

When stored feed is considered the concentrations should be corrected for decay between harvest and consumption by the anima 1. The decay correction can be made using Equation 4.3-18 applied to $C_{F}$ with the holdup time representing the storage time.

The total aose received from terrestrial ingestion pathways is the sum of the dose received from food crops and animal products as follows.

$$
D_{t_{0}}=\sum_{n=1}^{N} D F_{0}^{n}\left(U_{a} c_{a}^{n} p_{a}^{n}+U_{v} c_{v}^{n} p_{v}^{n}\right)
$$


where:

$$
\begin{aligned}
& D_{\text {to }} \text { - ingestion dose from terrestrial pathways for organ } 0 \text {, rem/year } \\
& \mathrm{DF}_{0}^{\mathrm{n}} \text { - ingestion dose commitment factor for radionuclide } \mathrm{n} \text { and } \\
& U_{a} \bullet \text { annual consumption rate of animal product, } \mathrm{kg} / \text { year } \\
& P_{a}^{n} \text { - fraction of radionuclide } n \text { remaining in animal product after } \\
& \text { harvest anc preparation for consumption, dimensionless } \\
& U_{V} \bullet \text { annual consumption rate of food crop, } \mathrm{kg} / \text { year } \\
& P_{v}^{n} \text { - fraction of radionuclide } n \text { remaining in food after harvest and }
\end{aligned}
$$

When there are more than one animal products or food crops grown at a site (which is usually the case) then the terms of Equation 4.3-20 must be summea over all arimal products or food crops. The removal fraction, $P_{a}^{n}$, for animal product preparation is usually set to unity representing no removal.

\subsubsection{Direct Exposure from Contained Sources}

The direct exposure pathway represents the penetrating radiation dose received trom sources contained onsite. Examples of such sources incluce particle accelerator facilities and gamma irradiation facilities. The principal considerations in estimating offsite exposures from such sources are

- establishing the dose rate at a given location

- extrapolating the dose rate to offsite locations based on radiation transport models

DOE contractors provide monitoring at site boundaries where the potential exists for offiste penetrating radiation exposure. These measurements can form the basis for estimating the dose rates at distances beyond the site boundary. 
The principal penetrating radiations of concern are photons and neutrons. Relatively simple formulas may be used to estimate the decrease in dose rate as a function of distance for these radiations. The photon distance relationship can be expressed as

$$
D(a)=D_{0} \frac{B(d, E) e^{-\mu} \gamma^{d}}{4 \pi d^{2}}
$$

where:

$$
\begin{aligned}
& D(d) \text { - dose rate at a distance } d \text { from the source, rem } / \mathrm{hr} \\
& D_{0} \text { - cose rate at the source, rem/hr } \\
& B\left(a, E_{\gamma}\right) \text { - photon energy buildup factor for photons of energy } E \\
& \text { traveling through a distance } d \text { of air, dimensionless } \\
& d \bullet \text { distance from source, } m \\
& \mu_{\gamma} \text { - total energy attenuation coefficient for photons of energy } E \text { in } \\
& \text { air, } m^{-1}
\end{aligned}
$$

when the dose rate at a given distance $\left(d_{1}\right)$ is known the dose rate at other distances can be estimated using the above expression modified as follows.

$$
D\left(d_{2}\right)=D\left(d_{1}\right)\left(\frac{d_{1}}{d_{2}}\right)^{2} \frac{B\left(d_{2}, E_{\gamma}\right)}{B\left(d_{1}, E_{\gamma}\right)} e^{-\mu_{\gamma}\left(d_{2}-d_{1}\right)}
$$

where:

$$
\begin{aligned}
& D\left(a_{2}\right) \bullet \text { dose rate at desired distance } d_{2} \text {, rem/hr } \\
& D\left(d_{1}\right) \bullet \text { measure cose rate at distance } a_{1}, r e m / h r
\end{aligned}
$$

and other terms are as previously defined.

The value for the photon energy exposure buildup factor can be estimated by several empirical formulas or tabulated values (Chiton 1968). Emperical formulas recommended for estimating the buildup factor include the following: 
- Berger's formula

$$
B\left(a, E_{\gamma}\right)=1+a \mu_{\gamma} d \exp \left(b d \mu_{\gamma}\right)
$$

- Capo's formula

$$
\begin{aligned}
B\left(d, E_{\gamma}\right) & =\sum_{i=0}^{3} \beta_{j}\left(\mu_{\gamma} d\right)^{i} \\
\beta_{i} & =\sum_{j=0}^{4} c_{i j}\left(\frac{1}{E_{\gamma}}\right)
\end{aligned}
$$

where $a, b$ and, $c_{i j}$ are emperical constants dependent on photon energy. Values for these constants are defined in the review by Chilton (1968). Numerical values of the buildup factor as a function of mean-free-path length and photon energy are also given by Chilton. The tabulated values, the Berger formula or the Capo formula should be used for the distances considered in offsite exposures.

A methou to estimate the distance dependence of neutron dose rate has been described by Thomas (1976) based on earlier reports of Rindi and Thomas (1973; 1975). The neutron aose rate is assumed to vary with distance according to the following equation

$$
H(d)=\frac{a e^{-d / \lambda}}{d^{2}}
$$

where:

$H(d)$ - neutron dose rate at a distance $d$ from the source (or accelerator target), rem/hr

d distance from the source to the exposure location, $m$

a proportionality constant, $r e m \mathrm{~m}^{2} / \mathrm{hr}$

$\lambda$ - effective neutron attenuation length, m. 
Values for the neutron attenuation length vary from $250 \mathrm{~m}$ (for accelerators limited to neutrons below about $50 \mathrm{MeV}$ ) to $2850 \mathrm{~m}$ (for neutrons in the range of $\sim 100 \mathrm{MeV}$ ) (Thomas 1976). When the dose rate is known at a given distance $d_{1}$ the dose rate can be estimated at other distances by the following equation.

$$
H\left(d_{2}\right)=H\left(d_{1}\right)\left(\frac{d_{1}}{d_{2}}\right)^{2} e^{-\left(d_{2}-d_{1}\right) / \lambda}
$$

where:

$H\left(d_{2}\right)$ - neutron dose rate at the distance of interest $d_{2}$, rem/hr

$H\left(d_{1}\right) \bullet$ meausred neutron dose rate at a distance $d_{1}$, rem/ hr

and other terms are as previously defined.

\subsection{DOSIMETRY}

The purpose in performing an environmental consequence analys is is to determine whether or not the routine release of radioactivity and penetrating radiation is within acceptable limits. The criteria for determining acceptability involve two parallel methods of analysis. The first method compares calculated or measured activity levels in air or water to appropriate Concentration Guides as defined in DOE Order 5480.1 Chapter XI (1981a).

Comparison of calculated dose commitments to dose standards is the second method recommended for determining acceptability of annual releases. This method requires a complete exposure pathway analysis to determining the 50-year dose commitment from releases occurring during the year of interest. The calculated doses are compared to the dose standards defined in DOE Order 5480.1 Chapter XI (1981a). While the dose guides are not well defined in the DOE order, they should be assumed to represent the 50-year dose commitment from uptake received in the year of plant operation. This method requires dosimetry models to determine the dose conversion factors as defined in Sections $4.1,4.2$ and 4.3 . 
The following Sections discuss these two methods for determining acceptability of annual releases.

\subsubsection{Use of CG Values}

The Concentration Guides (CG) are based on radiation standards defined by DOE (1981a). Continuous exposure to the stated CG values will result in an annual dose commitment to an individual approximately equal to the radiation standard. The radiation standards are shown in Table 3.4-1.

Concentration Guide values are defined for each radionuclide for air and water for controlled and uncontrolled areas. The values for uncontrolled areas are applicable to routine releases from DOE contractor facilities. CG values are also presented for mixtures of radionuclides. Use of Concentration Guides to determine acceptability of release is appropriate for airborne and waterborne releases when contributions from farm products or aquatic foods are not likely to pose a significant exposure pathway. When any of these ingestion pathways are significant it is recommended that an exposure pathway analysis be performed. Results of the exposure pathway analysis can be used to determine acceptability of releases by comparison with annual dose standards.

\subsubsection{Dosimetry Models}

When a complete environmental exposure pathway analys is is performed it is necessary to convert radionuclide exposure and uptakes to radiation dose. This requires dose commitment conversion factors as indicated for each pathway in Sections 4.1, 4.2 and 4.3. Models for calculating these dose conversion factors are described in this section.

The recommended models were selected to be compatible with the models originally used to determine the relationship between radiation standards and Concentration Guide values defined by DOE (1981a). These models are based on the methodology originally developed and recommended by the International Commission on Radiological Protection in 1959 (ICRP 1959). The ICRP has recently recommended a new method to estimate the radiation dose due to uptake of radionuclides (ICRP 1977; ICRP 1979). While the new method uses more recent data and is more complex, the originally recommended method should provide a reasonable estimate of the radiation dose received by individuals. Until the 
radiation standards and Concentration Guides have been re-evaluated to reflect the newer method there is no real advantage in changing the procedures currently used to determine acceptability of annual releases from DOE contractor facilities.

Implementation of the exposure pathway models requires four types of dose conversion factors:

$$
\begin{aligned}
& D_{w}^{n} \bullet \text { external exposure for submersion in water for radionuclide } n \text {, } \\
& \mathrm{rem} / \mathrm{hr} \text { per Ci/e } \\
& D_{p}^{n} \text { - external exposure from standing on an infinite plane source of } \\
& D F_{0}^{n} \text { - ingestion dose commitment factor for organ o and radionuclide }
\end{aligned}
$$

In addition to these factors, the external exposure pathway to airborne plumes requires dose conversion factors depending on the type of model being used (i.e., semi-infinite or finite). These factors have been described in Section 4.3.1.

Dose rate conversion factors for external exposure have been calculated and reported in the literature (Kocher 1979; Napier et a1. 1980; and USNRC 1977c). Equations used to estimate external dose conversion factors were presented by Kocher (1979) for immersion in contaminated air (semi-infinite plume) and water and for exposure to contaminated ground. The reader is refered to the report by Kocher for details of the calculations.

The models for implementation of the original ICRP internal dosimetry methodology (ICRP 1959) were discussed in Section 3.4.2. These models can be used to estimate inhalation and ingestion dose conversion factors required to convert radionuclide intake to organ dose commitments. Details of these models 
will not be discussed here; the reader is refered to the referenced reports. Values of dose commitment conversion factors have been calculated and are reported in the literature (USNRC 1977c; Hoenes and Soldat 1977).

\subsection{SUMMARY OF RECOMMENDATIONS}

The following is a summary of recommended models and methods. Compliance with acceptable release criteria (DOE 1981a) can be shown either by comparison of measured concentrations with concentration guide values or by comparison of calculated doses with dose limits. The dose calculations involve a complete pathway analysis covering a broad range of modeling areas. Models recommended for these areas are as follows:

- External exposure to penetrating radiation from particle accelerators can be estimated from measured exposure rates with extrapolation to longer distances using the model reported by Thomas (1976).

- Dispersion of airborne materials can be estimated using the crosswind averaged Gaussian plume model with submodels to account for special effects as follows:

- Plume rise--momentum model of (Briggs 1975)

- Downwash--Gifford model (1972)

- Building wake correction--USNRC (1977b)

- Terrain Elevation--USNRC (1977b)

- Dry deposition--effective deposition velocity (USNRC 1977b)

- Wet deposition--Engleman (1968)

- Plume depletion--source depletion model of USNRC (1977b) or surface/source hybrid model of Horst (1979a, 1979b)

- Mixing depth--uniform mixing model of Turner (1969)

- Waterborne transport should be estimated using site specific models or results of site studies.

- Calculation of external exposure to an airborne plume is recommended as follows. 1. For ground-level releases, exposure to the plume may 
be ignored for radionuclides other than noble gases. 2. For elevated releases (i.e., from stacks at $80 \mathrm{~m}$ or higher), external exposure should be included for all radionuclides using a finite plume correction. 3. A semi-infinite plume calculation may be used for noble gas releases below 50 meters.

- External exposure to contaminated ground can be estimated using the infinite plane model.

- External exposure to contaminated shoreline can be estimated using the sediment concentration model of Soldat et al. (1974) and the inifinite plane model with a shore width correction.

- Ingestion exposure can be estimated using the terrestrial and aquatic food pathway models defined in Regulatory Guide 1.109 (USNRC 1977c) and Napier et a1. (1980).

- Internal dosimetry can be described using the methods defined by the International Commission on Radiological Protection (ICRP 1959). 


\subsection{REFERENCES}

Anspaugh, L. R., J. H. Shinn, P. L. Phelps and N. C. Kennedy. 1975. Resuspension and Redistribution of Plutonium in Soils. Health Phys. 29:571-582.

Bass, A., D. G. Strimaitis and B. A. Egan. 1981. Potential Flow Model for Gaussian Plume Interaction with Simple Terrain Features. EPA-600/4-81-008. Environmental Research and Technology, Inc., Concord, Massachusetts.

Briggs, G. A. 1969. "Plume Rise". AEC Critical Review Series. TID-25075. Clearinghouse for Federal Scientific and Technical Information, Springfield, Virginia.

Briggs, G. A. 1975. Plume Rise Predictions. National Oceanic and Atmospheric Administration. Oak Ridge, Tennessee.

Burson, Z. G., A. E. Profio. 1975. Structure Shielding from Cloud and Fallout Gamma Ray Sources for Assessing the Consequences of Reactor Accidents. EGG1183-1670, EGaG, Inc., Las Vegas, Nevada.

Burt, E. W. 1977. Valley Model User's Guide. EPA-450/2-77-18, U.S. Environmental Protection Agency Dispersion Program, available from the U.S. Environmental Protection Agency, Office of Air Quality Planning and Standards, Research Triangle Park, North Carolina.

Busse, A. D. and J. R. Zimmerman. 1973. User's Guide for the Climatological and Dispersion Model. EPA-R4-73-024. U.S. Environmental Protection Agency, Research Triangle Park, North Carolina.

CEC. 1979. Methodology for Evaluating the Radiological Consequences of Radioactive Effluents Released in Normal Operations. Doc. No. V/3865/79-EN,FR. Prepared for Commission of the European Communities by National Radiological Protection Board Harwell, Didcot, United Kingdom and Commisariat A L'Energie Atomique, CEN Fontenay-aux-Roses, France.

Chilton, A. B. 1968. "Buildup Factor" in Engineering Compendium on Radiation Shielding Vol. I. R. G. Jaeger (Editor), Springer-Verlag, New York, New York.

Cooper, R. E. 1972. EGAD-A Computer Program to Compute Dose Integrals from External Gamma Emitters. DP1304. Savannah River Laboratory, Aiken, South Carolina.

Corey, J. C. and A. L. Boni. 1975. "Removal of Plutonium from Drinking Water by Community Water Treatment Facilities". IAEA-SM-199/81, Proceedings of the Transuranium Nuclides in the Environments, San Francisco, California, pp. 401408, November 17-21. 
Corley, J. P., D. H. Denham, R. E. Jaquish, J. E. Michels, A. R. Olsen and D. A. Waite. 1981. A Guide for: Environmental Radiological Surveillance at U.S. Department of Energy Installations. D0E/EP-0023. Department of Energy, Washington, D.C.

Denham, D. H. and J. K. Soldat. 1975. "A Study of Selected Parameters Affecting the Radiation Dose from Radionuclides in Drinking Water Downstream of the Hanford Project". Health Physics. 28:139-144.

Department of Energy. 1981 a. DOE Order 5480.1 Chapter XI - Requirements for Radiation Protection. U.S. Department of Energy, Washington, D.C.

Department of Energy. 1981b. DOE Order 5484.1-Environmental Protection, Safety, and Health Protection Information and Reporting Requirements. U.S. Department of Energy, Washington, D.C.

Drake, R. L. and S. M. Barrager. 1979. Mathematical Models for Atmospheric Pollutants. EPRI Report EA-1131. Electric Power Research Institute, PaTo Alto, California.

Egan, B. A. 1975. "Turbulent Diffusion in Complex Terrain". Lecture on Air Pollution and Environmental Impact Analys is--AM Workshop on Meteorology and Environmental Assessment. American Meteorological Society, Boston, Massachusetts, pp. 123-124.

Eimultis, E. C. and M. G. Konicek. 1972. "Derivations of Continuous Functions for the Lateral and Vertical Atmospheric Dispersion Coefficents". Atm.

Environ. 6:859-863.

Engleman, R. J. 1968. "The Calculation of Precipitation Scavenging". In Meteorology and Atomic Energy. D. H. Slade, Editor, USAEC TID-24190, pp. 208221 .

Freke, A. M. 1967. "A Model for the approximate Calculation of Safe Rates of Discharge of RAdioactive Wastes into Marine Environments". Health Physics, $13: 743-758$.

Gifford, F. A., Jr. 1972. Atmospheric Transport and Dispersion of Cities. Nucl. Saf. 13(5):391-402.

Gifford, F. A., Jr. 1976. "Turbulent Diffusion-typing Schemes: A Review" Nucl. Saf. $17(1): 68-86$.

Hanna, S. R., G. A. Briggs, and R. P. Hosker, Jr. 1982. Handbook on Atmospheric Diffusion, DOE/TIC-11223, U.S. Department of Energy, Washington, D.C.

Hoenes, G. R. and J. K. Soldat. 1977. Age-Specific Radiation Dose Commitment Factors for a One-Year Chronic Intake. NUREG-0172. U.S. Nuclear Regulatory Commission, Washington, D.C. 
Holzworth, G. C. 1972. Mixing Heights, Wind Speeds, and Potential for Urban Air Pollution Throughout the Contiguous United States. AP101. U.S. Environmental Protection Agency, Research Triangle Park, North Carolina.

Horst, T. W. 1979a. "A Review of Gaussian Diffusion-Deposition Models." In Atmospheric Sulfur Deposition. Ann Arbor Science Publishers, Inc., Ann Arbor, Michigan.

Horst, T. W. 1979b. "The Annual-Average Effect of the Deposition-Resuspension Process on Airborne Contamination Near the Surface." Atmospheric Environment, Vol. 13, pp. 791-79b, Pergamon Press.

IAEA. 1980. Atmospheric Dispersion in Nuclear Power Plant Siting. Safety Series No. 50-SG-S3. International Atomic Energy Agency, Vienna.

ICRP. 19by. Report of Committee II on Permissible Dose for Internal Radiation. International Commission on Radiological Protection. Publication 2, Pergamon Press. New York, New York.

ICRP. 1972. The Metabolism of Compounds of Plutonium and Other Actinides. International Commission on Radiological Protection. Publication 19, Pergamon Press. New York, New York.

ICRP. 1975. Report of the Task Group on Reference Man. International Commission on Radiological Protection, Publication 23, Pergamon Press, New York, New York.

ICRP. 1977. Recommendations of the International Commission on Radiological Protection. International Commission on Radiation Protection, Publication 26, Pergamon Press, 0xford.

ICRP. 197y. Limits for Intakes of Radionuclides by Workers. International Commission on Radiological Protection, Publication 30, Part 1, Pergamon Press, New York, New York.

Kocher, D. C. 1979. Dose-Rate Conversion Factors for External Exposure to Photon and Electron Radiation from Radionuclides Occurring in Rout ine Releases from Nuclear Fuel Cycle Facilities. NUREG/CR-0494. U.S. Nuclear Regulatory Commission, Washington, D.C.

Lahti, G. P., R. S. Hubner and J. C. Golden. 1981. "Assessment of -Ray Exposures Due to Finite Plumes." Health Physics 41:319.

Lange, R. 1973. AUP IC - A Three Dimensional Computer lode for the Study of Pollutant Dispersal and Deposition Under Complex Conditions. UCRL-51462. Lawrence Livermore Laboratory, Livermore, California. 
Lindebaum, S. J. 1961. "Shielding of High Energy Accelerators," International Conference on High Energy Accelerators. Brookhaven National Laboratory, Brookhaven, New York.

MacCracken, M. C., D. J. Wuebbles, J. J. Waltson, W. H. Duewer and K. E. Grant. 1975. The Livermore Regional Air Quality Model: I. Concept and Development.

UCRL -77475 , Pt. 1, Rev. 2. Lawrence Livermore Laboratory, University of California, Livermore, California.

Markee, E. H., Jr. 1967. "A Parametric Study of Gaseous Plume Depletion by Ground Surface Adsorption". Proceedings of USAEC Meteorological Information Meeting, C. A. Mawson, Editor, AECL-2787, pp. 602-613.

Moore, R. E., C. F. Baes III, L. M. McDowell-Boyer, A. P. Watson, F. 0. Hoffman, J. C. Pleasant, and C. W. Miller. 1979. AIRDOS-EPA: A Computerizea Methodology for Estimating Environmental Concentrations and Dose to man from Airborne Releases of Radionuclides. EPA 520/1-79-009. U.S. Environmental Protection Agency, Washington, D.C.

Morrow, P. E., D. V. Bates, B. R. Fish, T. F. Hatch and T. T. Mercer. 1906. "Deposition and Retention Models for Internal Dosimetry of the Human Respiratory Tract". Health Physics 12:173.

Napier, B. A. 1981. Standardized Input for Hanford Environmental Impact Statements - Part I, PNL-3509 PT 1, Pacific Northwest Laboratory, Richland, WA.

Napier, B. A., W. E. Kennedy, Jr. and J. K. Solaat. 1980. PABLM - A Computer Program to Calculate Accumulated Radiation Dose from Radionuclides in the Envirorment. PNL-3209, Pacific Northwest Laboratory, Richland, Washington.

Napier, B. A., R. L. Roswel 1, W. E. Kennedy, Jr. and D. L. Strenge. 1980. ARRKG and FOOD - Computer Programs for Calculating Radiation Dose to Man from Radionuclides in the Environment. PNL-3180. Pacific Northwest Laboratory, Richland, Washington.

NCRP. 1975. Natural Background Radiation in the Unitea States. Report No. 45. National Council on Radiation Protection and Measurements, Washington, D.C.

Pelletier, C. A. and J. D. Zimbrick. 1970. "Kinetics of Environmental Radioiodine Transport Through the Milk-Food Chain". Environmental Surveillance in the Vicinity of Nuclear Facilities, W. E. Reinig, Editor, Charles C. Thomas Publishers, Springfield, Illinois.

Poston, J.W. and W. S. Snyder. 1974. A Model for Exposure to a Semi-Infinite Cloud of a Photon Emitter, Health Phys 26(4):287-293.

Powe11, D. C., H. L. Wegley and T. D. Fox. 1977. MESODIF-II: A Variable Trajectory Plume Segment Model to Assess Ground-Level Air Concentrations and Deposition of Routine Effluent Releases from Nuclear Power Facilities. PNL-2419. Pacific Northwest Laboratory, Richland, Washington. 
Reynolds, S. D., M. K. Liu, T. A. Hecht, P. M. Roth and J. H. Seinfeld. 1973. "Mathematical Modeling of Photochemical Air Pollution: III. Evaluation of the Mode1". Atm. Envir. 8,563.

Rindi, A. and R. H. Thomas. 1973. The Radiation Environment of High Energy Accelerators. Ann. Rev. Nucl. Sci. 23, 315.

Rindi, A. and R. H. Thomas. 1975. "Skyshine." Particle Accelerators 7:23.

Rosen, L. C. 1977. A Review of Air Quality Modeling Techniques. LBL-5998, Lawrence Berkeley Laboratory, Berkeley, California.

Sagendorf, J.F. 1974. A Program for Evaluating Atmospheric Dispersion from a Nuclear Power Station. NOAA Technical Memoramdum ERL ARL-42. Air Resources Laboratory, Idaho Falls, Idaho.

Sagendorf, J.F. and J. T. Gol1. 1977. XOQDOQ Program for the Meteorological Evaluation of Routine Effluent Releases at Nuclear Power Stations. NUREG-0324. U.S. Nuclear Regulatory Commission, Washington, D.C.

SLAC. 1980. Annual Environmental Monitoring Report. SLAC-228, Standford Linear Accelerator Center, Stanford Unviersity, Stanford, California.

Slade, D. H. 1968. Meteorology and Atomic Energy. U.S. Atomic Energy Cominission, Washington, D.C.

Slinn, W. A. N. 1975. Some Approximations for the Wet and Dry Removal of Particles and Gases from the Atmosphere. BNWL-SA-5489. Pacif ic Northwest Laboratory, Richland, Washington.

Snyder, W. S., M. R. Ford, G. G. Warner and S. B. Watson. 1974. A Tabulation of Dose Equivalent per Microcurie-Day for Source and Target Organs of an Adult for Various Radionuclides. ORNL-5000. Oak Ridge National Laboratory, Oak Ridge, Tennessee.

Soldat, J. K., N. M. Robinson and D. A. Baker. 1974. Models ana Computer Codes for Evaluating Environmental Radiation Doses. BNWL-1754, Pacific Northwest Laboratory, Richland, Washington.

Start, G. E. and L. L. Wendel1. 1974. Regional Effluent Dispersion Calculations Considering Spatial and Temporal Meteorological Variations. Preprint volume for Symposium on Atmospheric Diffusion and Air Pollution. American Meteorological Society, Santa Barbara, California.

Strenge, D. L. and E. C. Watson. 1973. KRONIC - A Computer Program for Calculating Annual Average External Doses from Chronic Atmospheric Releases of Radionuclides. BNWL-B-264. Pacific Northwest Laboratory, Richland, washington. 
Strenge, D. L., J. K. Soldat and E. C. Watson. 1978. A Review of Methodology for Accident Consequence Assessment. NUREG/CR-0545, PNL-2633. Pacific Northwest Laboratory, Richland, Washington.

Thomas, R. H. (ed.). 1976. The Environmental Surveillance Program of the Lawrence Berkeley Laboratory. LBL-4678. Lawrence Berkeley Laboratory, University of California, Berkeley, California.

Thompson, S. E., C. A. Burton, D. J. Quinn and Y. C. Ng. 1972. Concentration Factors of Chemical Elements in Edible Aquatic Organisms. UCRL-50564, Rev. 1, Lawrence Livermore Laboratory, Livermore, California.

Turner, D. B. 1969. Workshop of Atmospheric Dispersion Estimates. Public Health Service, Publication No. 999-AP-26. U.S. Department of Health Education and Welfare, Washington, D.C.

Turner, D. B. 1979. "Atmospheric Dispersion Modeling, A Critical Review". Air Pollution Control Association Journal. 29(5):502-519 (May).

U.S. Lepartment of Commerce. 1954. "Permissible Dose from External Sources of Ionizing Radiation". Handbook 59. Washington, D.C.

USNRC. 1975. Reactor Safety Study; an Assessment of Accident Risks in U.S. Commercial Nuclear Power Plants, Appendix VI, Calculation of Reactor Accident Consequences. WASH-1400(NUREG 75/014). U.S. Nuclear Regulatory Commission, Washington, D.C.

USNRC. 1y77a. Estimating Aquatic Dispersion of Effluents from Accidental and Routine Reactor Releases for the Purpose of Implementing Appendix I. Regulatory Guide 1.113, Rev. 1. U.S. Nuclear Regulatory Commission, Washington, D.C.

USNRC. 1977b. Methods for Estimating Atmospheric Transport and Dispersion of Gaseous Effluents in Routine Releases from Light-Water-Cooled Reactors. Regulatory Guide 1.111, Rev. 1. U.S. Nuclear Regulatory Commission, Washington, D.C.

USNRC. 1977c. Calculation of Annual Doses to Man from Routine Releases of Reactor Effluents for the Purpose of Evaluating Compliance with 10CFR Part 50 , Appendix 1. Regulatory Guide 1.109, Rev. 1, U.S. Nuclear Regulatory Commission, Washington, D.C.

USNRC. 1978. Liquid Pathway Generic Study. NUREG-0440. U.S. Nuclear Regulatory Commission, Washington, D.C. 


\section{Additional Bibliography}

The following references are provided as background information sources for environmental assessment modeling.

Hoffman, F. 0., D. L. Schaeffer, C. W. Miller and C. T. Garten, Jr. 1977. Proceedings of a Workshop on the Evaluation of Models Used for the Environmental Assessment of Radionuclide Releases. CONF-770901, 0ak Ridge National Laboratory, Oak Ridge, TN.

ONWI. 1981. Tabulation of Waste Isolation Computer Models. ONWI-78. Prepared by Science Applications, Inc. for Office of Nuclear Waste Isolation, Columbia, $\mathrm{OH}$.

Strenge, D. L., J. K. Soldat and E. C. Watson. 1978. A Review of Methooology for Accident Consequence Assessment. NUREG/CR-0545 (PNL-2633), U.S. Nuclear Regulatory Comrnission, Washington, DC . 


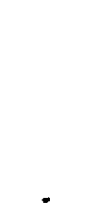




\section{DISTRIBUTION}

No. of

Copies

OFFSITE

3 J. H. Barry, Director Operational Safety Division DOE-Idaho Operations Office 550 Second Street

Idaho Falls, ID 83401

J. E. Baublitz

Department of Energy, ER-532

Washington, D.C. 20545

J. E. Behrend

Department of Energy, NE-33

Washington, D.C. 20545

3 B. Church

Operations Support Division DOE-Nevada Operations Office

P.0, Box 14100

Las Vegas, NV 89114

27 DOE Technical Information Center

G. C. Facer

Department of Energy, DP-29.1

Washington, D.C. 20545

W. A. Frankhauser

Department of Energy, DP-122

Washington, D.C. 20545

F. X. Gavigan

Department of Energy, NE-550

Washington, D.C. 20545

6 C. D. Jackson, Director

Environment, Safety \& Program Support Division

DOE-San Francisco Operations Office

1333 Broadway

Oakland, CA 94612
No. of

Copies
J. R. Maher

Department of Energy, EP-34

Washington, D.C. 20545

5 J. J. Mangeno

Naval Reactors

Department of Energy, NE-60

Washington, D.C. 20545

S. Matovich

Department of Energy, DP-13

Washington, D.C. 20545

6 R. M. Moser, Director Operational and Environmental Safety Division DOE-Chicago Operations and Regional office 9800 South Cass Avenue Argonne, IL 60439

W. E. Mott

Department of Energy, EP-32

Washington, D.C. 20545

M. A. Mueller

Burns and Roe

800 Kinderkamack Road

Oradel1, NJ 07649

3 W. A. Reese, Director

Safety and Environment Division

DOE-Savannah River Operations Office

P.0. Box A

Aiken, SC 29801

8 J. R. Roeder, Director

Operational Safety Division

DOE-Albuquerque Operations Office

P.0. Box 5400

Albuquerque, NM 87115 
No. of

Copies

J. W. Rowen

Department of Energy, NE-30

Washington, D.C. 20545

2 D. Schweller, Area Manager DOE-Brookhaven Area Office Upton, NY 11973

\section{G. Sherwood}

Department of Energy, NE-520

Washington, D.C. 20545

R. J. Stern

Department of Energy, EP-33

Washington, D.C. 20545

6 W. H. Travis, Director

Safety and Environmental

Control Division

DOE-0ak Ridge Operations Office P.O. Box E

Oak Ridge, TN 37830

B. W. Wachholz

Department of Energy, EP-32

Washington, D.C. 20545

10

C. G. Welty

Office of Operational Safety

Department of Energy, EP-321

Washington, D.C. 20545

E. R. Williams

Department of Energy, EP-33

Washington, D.C. 20545

\section{ONSITE}

6

DOE Richland Operations office

R. E. Gerton (5)

H. E. Ransom
No. of

Copies

\section{Pacific Northwest Laboratory}

W. J. Bair

J. B. Brown

J. P. Corley (5)

T. H. Essig

W. A. Glass

R. E. Jaquish

W. E. Kennedy, Jr.

W. D. McCormack

B. A. Napier

J. M. Selby

J. K. Soldat

D. L. Strenge (30)

R. G. Schreckhise

E. C. Watson

N. A. Wogman

Technical Information (5)

Publishing Coordination js (2) 